\title{
Sources of uncertainty in the Mazama isopachs and the implications for interpreting distal tephra deposits from large magnitude eruptions
}

\author{
Hannah M. Buckland ${ }^{1}$ (D) $\cdot$ Katharine V. Cashman $^{1} \cdot$ Samantha L. Engwell ${ }^{2} \cdot$ Alison C. Rust $^{1}$
}

Received: 5 September 2019 / Accepted: 10 January 2020 / Published online: 6 February 2020

(C) The Author(s) 2020

\begin{abstract}
Estimating the area of tephra fallout and volume of large magnitude eruptions is fundamental to interpretations of the hazards posed by eruptions of this scale. This study uses the tephra from the caldera forming eruption of Mount Mazama (Crater Lake, OR, USA) to demonstrate the challenges faced when working with large prehistoric tephra deposits and outlines the methodologies required to determine eruption volume and magnitude. We combine $>250$ Mazama tephra occurrences, reported by a range of disciplines (including archaeology, paleoclimatology and volcanology), with new field studies to better understand the extent of the distal tephra. We find that the Mazama tephra has been remobilised to varying degrees over the past 7000 years, so each tephra locality was appraised for the likelihood that it records primary tephra fallout. We designated 45 of the distal (> $100 \mathrm{~km}$ from source) tephra sites as suitable for use in the production of isopachs using a spline fitting method. The new distal isopachs were then integrated with proximal fallout data and estimates of the ignimbrite volume from previous studies to revise the estimated bulk erupted volume from the climactic Mazama eruption to $\sim 176 \mathrm{~km}^{3}\left(\sim 61 \mathrm{~km}^{3}\right.$ dense-rock equivalent; DRE). This study demonstrates the importance of collating tephra localities from a range of disciplines and that even remobilised deposits provide valuable information about the extent of the deposit. Interpreting remobilised deposits can provide insight into post-eruptive processes that could potentially pose secondary hazards following large magnitude eruptions. We also show that in some circumstances, remobilised deposits preserve important physical properties such as grain size.
\end{abstract}

Keywords Tephra $\cdot$ Crater Lake $\cdot$ Mazama $\cdot$ Isopachs $\cdot$ Remobilisation $\cdot$ Eruption volume

\section{Introduction}

Large, caldera-forming eruptions pose a potentially devastating hazard to human populations and the environment. For example, the tephra generated by a magnitude $(M) 7$ or greater

Editorial responsibility: P.-S. Ross

Electronic supplementary material The online version of this article (https://doi.org/10.1007/s00445-020-1362-1) contains supplementary material, which is available to authorized users.

Hannah M. Buckland

hannah.buckland@bristol.ac.uk

1 School of Earth Sciences, University of Bristol, Wills Memorial Building, Bristol BS8 1RJ, UK

2 British Geological Survey, The Lyell Centre, Research Avenue South, Edinburgh EH14 4AP, UK eruption can be dispersed across millions of square kilometres, posing immediate and long-term hazards (e.g. Tambora, 1815: Gertisser and Self 2015). In this paper, the term 'tephra' is used to refer only to fallout; deposits associated with pyroclastic density currents (ignimbrites) are discussed separately. Deducing the nature and scale of the hazards from large eruptions is challenging as their long repose period means eruptions of this scale have not been observed in modern times. Therefore, we are reliant on tephra deposits from prehistoric eruptions to inform our interpretations. Past eruptions are typically studied by mapping the tephra deposit in terms of thickness and grain size and then fitting the data using a range of models to approximate deposit extent, erupted volume, plume height and eruption magnitude (e.g. Carey and Sparks 1986; Pyle 1989, 2000; Bonadonna and Costa 2013). However, these methods often have limitations for large prehistoric eruptions that have dispersed fine ash over vast areas (e.g. Biass and Bonadonna 2011; Burden et al. 2013; Engwell et al. 2013). 
Estimating the volume of prehistoric eruptions is key to assessing the magnitude-frequency relationships which may provide insight into the driving forces of volcanism and inform future risk mitigation strategies (Mason et al. 2004; Self 2006; Newhall et al. 2018; Rougier et al. 2018). However, eruptive volume estimates of unobserved eruptions require detailed interpretations of tephra deposits (Froggatt 1982; Pyle 1989; Fierstein and Nathenson 1992). This is challenging for large eruptions where the distal tephra is often deposited offshore (e.g. Tambora, 1815: Kandlbauer and Sparks 2014) limiting our interpretive power unless an extensive offshore record is available to supplement the terrestrial record (e.g. the Campanian tephra; Engwell et al. 2014). Owing to its widespread, on-land distal tephra deposit (Fig. 1), the $\sim 7.7$ ka eruption of Mount Mazama in Oregon, USA, is an ideal, large $(M>$ 7; Crosweller et al. 2012; the LaMEVE database, VOLGRIPA; www.bgs.ac.uk/vogripa/view/controller.cfc?method=lameve) caldera forming eruption to study from this perspective (Williams 1942; Bacon 1983; Young 1990). Pacific deep-sea cores only record the Mazama tephra in turbidite deposits, not as a primary layer, supporting predominantly on-land tephra deposition (Fig. 2; Adams 1990). However, whilst the terrestrial Mazama tephra provides a unique opportunity to study a large prehistoric eruption, interpretation of the deposit is complicated by post-eruptive processes such as tephra remobilisation.

Remobilisation processes occur in the distal tephra deposits of large eruptions because of their wide spatial coverage and varied depositional environments. Tephra remobilisation is a secondary hazard acting over longer timescales than the primary hazards of the eruption. The remobilisation of tephra deposits is observed at a number of scales and can be initiated by fluvial, aeolian and gravitational processes. Documenting and studying sites where these processes are observed is key to enhancing our understanding of the processes and resulting hazards (Manville et al. 2000; Hadley et al. 2004; Lowe 2011; Gatti et al. 2013; Shapley and Finney 2015). For example, in the Younger Toba Tuff (YTT, $M \sim 9.1$ ) tephra, there is evidence of fluvial reworking and slumping at a number of distal sites in Malaysia and India $>350 \mathrm{~km}$ from source which altered the thickness and grain size (Gatti et al. 2011, 2013). Here we combine new field data with the extensive published data available for the distal Mazama tephra to better constrain the deposit extent and erupted volume. We identify and account for post-eruptive processes before producing new isopach maps and eruptive volume estimates.

\section{Background}

\section{The Mazama tephra}

Mount Mazama was a 3700-m-high stratovolcano built primarily of andesite and dacite lavas from $\sim 400$ to $40 \mathrm{ka}$ (Bacon and Lanphere 2006). During the Holocene, the climactic Mazama eruption formed modern day Crater Lake in Oregon, USA (Bacon 1983; Bacon and Druitt 1988; Bacon and Lanphere 2006). The eruption began with an increasingly violent Plinian phase before the onset of caldera collapse that produced large volume pyroclastic density currents (Williams 1942; Bacon 1983; Young 1990). The tephra from the climactic eruption is found as a visible layer across the western USA and Canada and as cryptotephra (a non-visible tephra layer) in Greenland (Hammer et al. 1980; Zdanowicz et al. 1999), Newfoundland (Pyne-O'Donnell et al. 2012), and the Great Lakes (Spano et al. 2017; Fig. 2c). Despite the extensive record of Mazama tephra and the importance of the tephra layers as an isochron, considerable uncertainty remains about the thickness distribution of the deposit.

Isopach maps are the most common way to represent the thickness of a tephra deposit and calculate erupted volume (Pyle 1989; Fierstein and Nathenson 1992; Bonadonna et al. 1998). However, constructing isopachs is challenging when there is insufficient and unreliable field data (Engwell et al. 2013). Therefore, for prehistoric eruptions such as the Mazama, the isopach maps contain a high degree of often unquantified uncertainty (Engwell et al. 2015), the effect of which is amplified when isopachs are hand drawn (Klawonn et al. 2014). The hand-drawn isopachs of the distal Mazama tephra in Fig. 1 demonstrate considerable variability reflecting the subjective interpretation by each of the authors. Additionally, all the isopach maps (Fig. 1) use a relatively small number of ash thickness measurements (less than 55) to reconstruct the deposit over an area that is $>1$ million square kilometres, equivalent to $\sim 1$ measurement per 20,000 km² (Lidstrom 1971; Matz 1987; Young 1990).

The challenges of interpreting the distal Mazama tephra have long been recognised and as a result, the betterpreserved deposits closer to source have been favoured for mapping and compositional studies (Williams 1942; Young 1990). In this study, we define distal as $>100 \mathrm{~km}$ from source and proximal as $\leq 100 \mathrm{~km}$ from the volcano. Mapping of the Plinian fall deposit by Williams (1942), Lidstrom (1971), and Young (1990) produced a high density of proximal tephra localities. Two distinct units were identified within the fall deposit, which is then capped by a fine ash layer, interpreted to be of co-ignimbrite origin (Fig. 3a; Young 1990). Here we integrate the proximal data collected by Young (1990) with previously reported and new distal localities to enhance our understanding of the primary tephra transport and deposition. Assimilating data sets from multiple disciplines, such as archaeology, palaeoclimatology and volcanology, requires an assessment of data quality and compatibility (see Lowe 2011). For example, a palaeoclimate study may only require that the tephra layer be identified for dating purposes and will therefore record limited physical information such as thickness (Heusser 1974). However, the observation that distal 
Fig. 1 Compilation of Mazama isopach maps. a Location map. Red rectangle outlines the extent of maps $(\mathbf{b}-\mathbf{e})$. b Isopach map from Lidstrom (1971), tephra thicknesses shown in centimetres. c Isopach map from Matz (1987) with zone of 'Distal Thickening' in black. $\mathbf{d}$ Isopach map by Young (1990). For the published isopachs $(\mathbf{b}, \mathbf{c})$ some thicknesses are not clearly stated in the relevant thesis and have been marked as 'ND'. e Minimum extent maps of the Mazama tephra from (1) Mullineaux (1974), (2) Westgate and Gorton (1981) and (3) Egan et al. (2015)
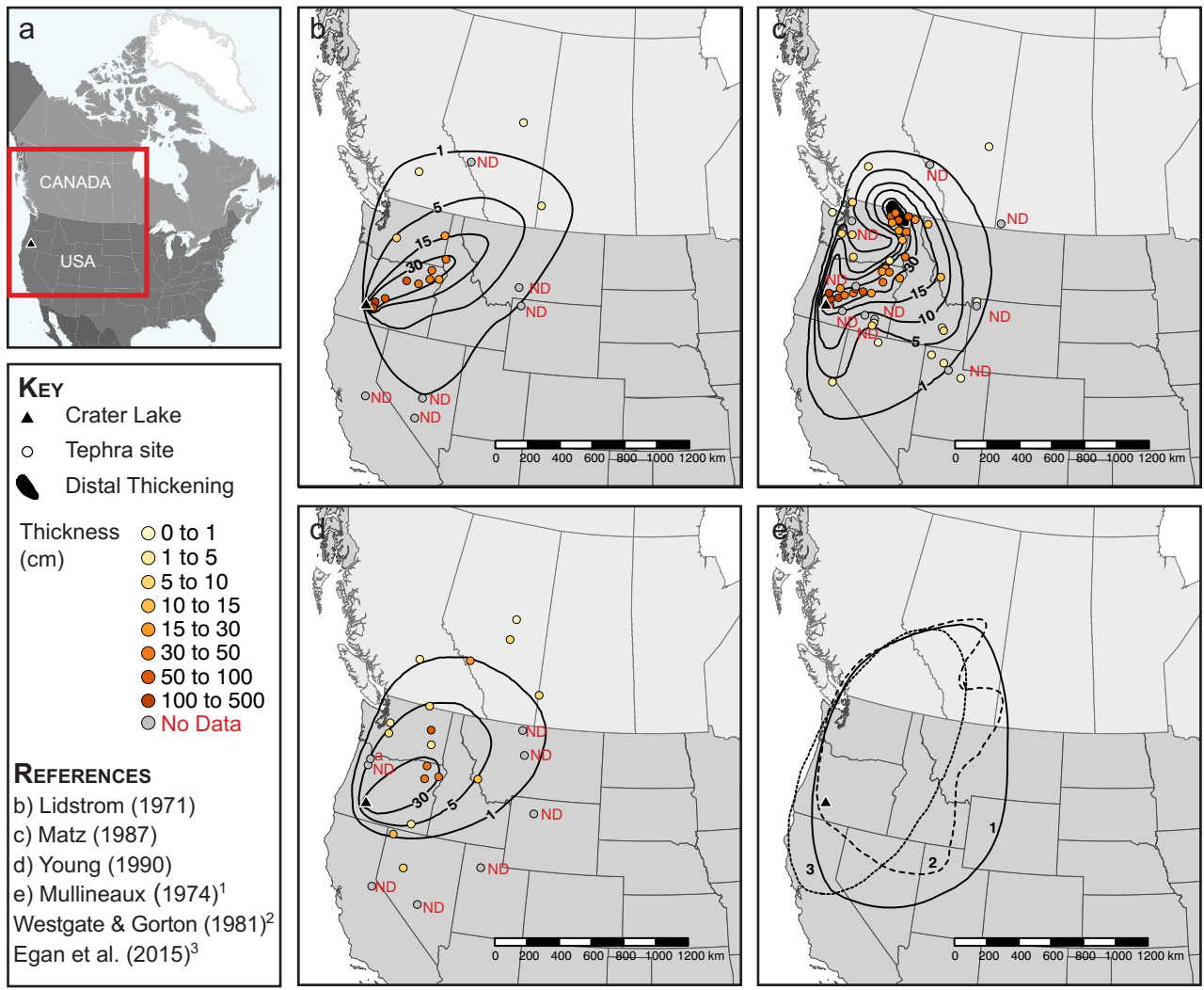

tephra exists at a given location, even without further details, is useful information.

\section{The volume of the Mazama eruption}

The challenge of quantifying the volume of the climactic Mazama eruption has been approached in a number of ways and has produced a range of volume estimates (Table 1). Some of the first estimates of dense-rock equivalent (DRE) volume were based on the volume of the caldera and reconstructed edifice. For example, Williams (1942) used the caldera depth to calculate an approximate caldera volume of $\sim 50 \mathrm{~km}^{3}$. Adding this to the assumed $\sim 30 \mathrm{~km}^{3}$ edifice, Williams estimated that $>70 \mathrm{~km}^{3}$ of material must have been ejected or removed by the climactic eruption. Williams and Goles (1968) and later Bacon (1983) revised those estimates to $\sim 60 \mathrm{~km}^{3}$. However, more recently, Bacon and Lanphere (2006) reconstructed the Mount Mazama edifice and estimated a volume of $\sim 112 \mathrm{~km}^{3}$. They attribute the discrepancy between the edifice and erupted volume to an incomplete knowledge of the collapse deposits in the caldera and the additional volume erupted by pre-climactic eruptions such as the Llao Rock and Cleetwood eruptions (Bacon and Lanphere 2006).

To estimate the bulk volume of the Mazama tephra deposit, multiple authors have used tephra thickness data (Williams 1942; Williams and Goles 1968; Lidstrom 1971; Young 1990; Table 1). Williams (1942) first estimate of $\sim 15 \mathrm{~km}^{3}$ was based on the thickness of the proximal fall deposit (< $100 \mathrm{~km}$ from source). The estimate was revised by Williams and Goles (1968) who included three distal thickness measurements which increased the estimate by $\sim 30 \mathrm{~km}^{3}$ (Table 1). The first estimate that used distal isopachs was $120 \mathrm{~km}^{3}$ by Lidstrom (1971); Fig. 1b). Using different isopachs and incorporating the thick proximal fallout, Young (1990); Fig. 1d) also calculated a volume of $\sim 120 \mathrm{~km}^{3}$. However, we would expect a discrepancy between these estimates because Lidstrom (1971) did not include the proximal fallout. This highlights the inconsistencies in volume estimates made from different isopach data (Fig. 1).

Converting the bulk erupted volume to a DRE volume requires assumptions of deposit density, which in turn depends on packing density and the vesicularity and composition of the clasts. The conversion to DRE volumes for deposits such as the Mazama tephra are complicated further by variations in the deposits. The Mazama tephra is composed of pumice, lithics and crystals, which have unique densities, morphologies and vesicularites, and the proportion of each component changes throughout the eruption (Lidstrom 1971; Bacon and Druitt 1988; Young 1990). The degree of deposit compaction also changes with grain size, depositional environment and time since deposition (Lidstrom 1971). These caveats for DRE calculations may explain some of the variability in DRE estimates found in Table 1. 
Table 1 Erupted volume estimates from the literature

\begin{tabular}{|c|c|c|c|c|c|}
\hline Reference & $\begin{array}{l}\text { Volume estimate } \\
\text { of caldera and } \\
\text { Mount } \\
\text { Mazama }\left(\mathrm{km}^{3}\right)\end{array}$ & $\begin{array}{l}\text { Bulk volume } \\
\text { estimate } \\
\left(\mathrm{km}^{3}\right)\end{array}$ & Method used to calculate bulk volume & $\begin{array}{l}\text { Ignimbrite } \\
\text { included }\end{array}$ & $\begin{array}{l}\text { DRE volume } \\
\text { estimate } \\
\left(\mathrm{km}^{3}\right)\end{array}$ \\
\hline Williams (1942) & 71 & 44 & $\begin{array}{l}\text { Estimated from the thickness of deposits } \\
\text { within } 100 \mathrm{~km} \text { from source }\end{array}$ & $\mathrm{Y}$ & 27 \\
\hline Williams and Goles (1968) & 62 & $55-71$ & $\begin{array}{l}\text { Exponential fit to plot of thickness versus distance } \\
\text { with } 3 \text { distal thicknesses }\end{array}$ & Y & 42 \\
\hline Lidstrom (1971) & - & $100-125^{\mathrm{b}}$ & $\begin{array}{l}\text { Volume of arcuate segments fit to distal isopachs } \\
\text { (Fig. 1b) }\end{array}$ & $\mathrm{N}$ & $57-64$ \\
\hline $\operatorname{Bacon}(1983)^{\mathrm{a}}$ & $46-58$ & 120 & - & - & $51-59$ \\
\hline Druitt and Bacon (1986) ${ }^{\mathrm{a}}$ & - & - & - & - & $47 \pm 7$ \\
\hline Young (1990) & - & 122 & $\begin{array}{l}\text { Exponential fit to log thickness versus square root } \\
\text { area plot using proximal and distal isopachs (Fig. 1d) }\end{array}$ & $\mathrm{N}$ & 45 \\
\hline Machida $(2002)^{a}$ & - & 78 & - & - & - \\
\hline $\begin{array}{l}\text { Bacon and Lanphere } \\
\text { (2006) }\end{array}$ & 112 & - & - & - & 50 \\
\hline Geyer and Martí (2008) ${ }^{\mathrm{a}}$ & $50-60$ & - & - & - & 42 \\
\hline Johnston et al. $(2014)^{\mathrm{a}}$ & - & 153 & - & - & $\sim 75$ \\
\hline $\begin{array}{l}\text { The LaMEVE database, } \\
\text { VOLGRIPA, https://www.bgs. } \\
\text { ac.uk/vogripa/view/controller. } \\
\text { cfc?method=lameve }{ }^{\mathrm{a}}\end{array}$ & - & 120 & - & - & 50 \\
\hline
\end{tabular}

${ }^{a}$ Method of volume estimation not stated; they are only in text values

${ }^{\mathrm{b}}$ This value was estimated for the volume $>100 \mathrm{~km}$ from source

Another source of variability in the bulk deposit volume estimates relates to the inclusion or exclusion of the ignimbrite volume (Table 1). Early work by Williams (1942) mapped the extent of the ignimbrite ('glowing avalanches') and estimated a bulk ignimbrite volume $\sim 29 \mathrm{~km}^{3}$, which he included in his bulk erupted volume (total $\sim 44 \mathrm{~km}^{3}$ ). More recent estimates of total erupted volume, by Young (1990), consider only the Plinian fall and distal tephra, or they are unclear as to whether the ignimbrite volume has been included (Bacon and Lanphere 2006; Johnston et al. 2014). It is likely that a significant proportion ( $>10 \%)$ of the total erupted volume is contained in the ignimbrite, as flows reached over $70 \mathrm{~km}$ from source and are $>80 \mathrm{~m}$ thick around the caldera (Williams 1942). For this reason, the inclusion of this volume is important when calculating eruption magnitude.

\section{Tephra remobilisation}

A major challenge of using tephra layers to understand prehistoric eruptions is recognising modifications that occurred after the initial deposition. Processes that can remobilise primary tephra range from small scale bioturbation (Griggs et al. 2015), local slumping and grain flow down slopes (Boygle 1999) to large scale debris flows (Manville et al. 2000) and resuspension by surface winds (Wilson et al. 2011). Even if a tephra layer is not remobilised, varied depositional settings lead to differential preservation and compaction that result in variations in the tephra thickness preserved (Blong et al. 2017). The effectiveness of transferring a tephra deposit to the stratigraphic record will depend on the background sedimentation, vegetation cover and slope angle (Cutler et al. 2018; Dugmore et al. 2018). For this reason, peat bogs and lakes are often favoured depositional settings for studying tephra stratigraphy (Watson et al. 2016; McNamara et al. 2019). The Mazama tephra is recorded not only in peat bogs (Harward and Youngberg 1969) and lakes (Long et al. 2014) but also in dry land sections (Young 1990; this study) and aeolian sediments (Sweeney et al. 2005). This means that each tephra locality will have experienced different preservation mechanisms and compaction, as well as being exposed to a variety of remobilisation processes. Furthermore, the effectiveness of preservation and remobilisation processes vary with the physical tephra properties (thickness, grain size, density; Cutler et al. 2018; Dugmore et al. 2018).

\section{Methods}

We implemented a variety of methods to constrain the distribution of the Mazama tephra and estimate the total bulk erupted volume. We compiled a database of distal tephra localities containing data from multidisciplinary sources and new field sites. Each tephra locality was assessed for evidence of tephra mobilisation based on information in the original publication, field observation or what is implied for the location in relation to surrounding topography. Finally, we used thickness data 
from the newly optimised locality database to generate a reproducible isopach map using a cubic B-spline method. The new isopachs were then used for erupted volume calculations.

\section{Compiling Mazama tephra localities}

We have amalgamated and extended several existing databases of Mazama tephra localities to produce a single database that records > 250 occurrences of Mazama tephra (Lidstrom 1971; Matz 1987; Young 1990; Hallett et al. 1997; Egan et al. 2015; Jensen et al. 2019; J A Westgate, pers. commun.). The database records physical information about the tephra layer at each locality, which complements that of Egan et al. (2015), whose focus was radiocarbon dating. The information used was gathered from scientific literature, Masters and $\mathrm{PhD}$ theses, geological maps and field guides, as well as new field sites outlined in this study. The coordinates, locality name, reference(s), sampling method and research discipline of the original paper are provided for each locality. Where available, the thickness, grain size and the degree of remobilisation are reported with the accompanying metadata. If separate studies report different thicknesses at the same locality, an average thickness is used. Similarly, if an author 'corrected' the thickness without explaining the rationale or method, the original thickness is used rather than the corrected value (Matz 1987). Key field observations are included for terrestrial sites and for lake core localities, the depth of the tephra in the core is reported. If multiple cores were taken from the same site, only one locality is entered into the database, but the number of cores at each locality and any variability in thickness and grain size is documented in the metadata.

\section{New field localities}

This study includes new observations from ten field localities (all > $100 \mathrm{~km}$ from source; Supplementary S1). The Mount Bachelor locality (site 46; Fig. 2b) is approximately equivalent to a site mapped by Young (1990). The site required a tephra pit $1.5 \mathrm{~m}$ deep to expose the Mazama tephra stratigraphy (Fig. 3a). The total thickness and thickness of different horizons were measured, and samples were taken in $5 \mathrm{~cm}$ intervals from the top down. The stratigraphy was split according to the units in Young (1990) with a lower and upper pumice unit and final fine co-ignimbrite ash.

At the Prineville Reservoir locality (site 50; Fig. 2b), the Mazama tephra had been reworked at the surface (Fig. 3b). This area was targeted based on previous studies (Harward and Youngberg 1969; Lidstrom 1971) that recorded Mazama ash in the area but provided no measurements of thickness or grain size. The Mazama tephra at the Mitchell locality (site 55; Fig. 2b) outcrops as a discontinuous layer which is interpreted as evidence of remobilisation (Fig. 3c). However, the presence of reverse grading in places may reflect the original stratigraphy.

We also examined seven sites $>450 \mathrm{~km}$ from Crater Lake (Fig. 2b). Some localities were previously documented in field guides (Carson and Pogue 1996) and Quaternary studies of the region (Waitt 1980). The sample sites were typically from riverbank, valley cut and roadcut exposures that required little excavation (Fig. 3d-g). No stratigraphic horizons could be identified in these deposits; therefore, only the total thickness was measured and bulk samples taken.
Fig. 2 Distal Mazama tephra sites compiled for this study. a Map of the western USA and Canada with sites of Mazama tephra > $100 \mathrm{~km}$ from source. b Inset map with field sites from this study highlighted in white symbols with the site number adjacent. c Map of the USA, Canada and Greenland with sites of Mazama cryptotephra (Hammer et al. 1980; Zdanowicz et al. 1999; Pyne-O'Donnell et al. 2012; Spano et al. 2017)
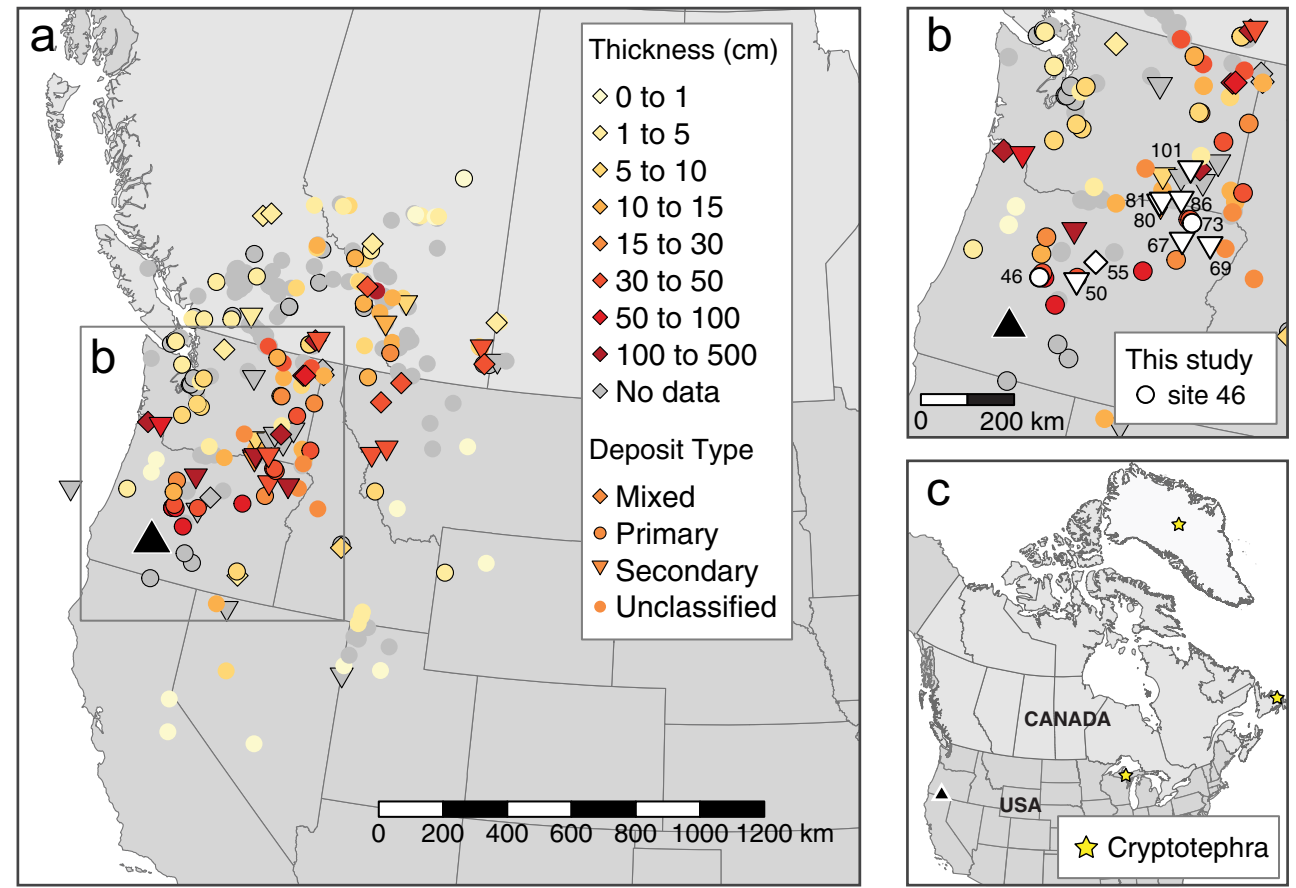
The grain size distributions (GSDs) of the tephra from the new field sites were measured by dry sieving from $-3 \varphi$ to $3 \varphi$ ( $8 \mathrm{~mm}$ to $125 \mu \mathrm{m})$ in half $\varphi$ intervals. The fine material was then measured using the Mastersizer $3000^{\mathrm{TM}}$ by Malvern Instruments Ltd. in the School of Geographical Sciences at the University of Bristol. We recombined the $3 \varphi$ sieve fraction with the fine material $(<125 \mu \mathrm{m})$ prior to laser diffraction so the two methods of measuring grain size can be combined using the overlap in the $3 \varphi$ fraction (Eychenne et al. 2012; McNamara et al. 2018). For sites $>450 \mathrm{~km}$ from source, only laser diffraction was required due to the fine grain size. The grain size statistics - mode, median (Md), sorting $(\sigma)$, skewness (Sk) and kurtosis $(K)$-were calculated using GRADISTAT (Folk and Ward 1957; Blott and Pye 2001).

\section{Interpolated isopachs}

We used a method of spline interpolation to interpret the thickness data collated in the database. Following the method outlined in Engwell et al. (2015), a cubic B-spline under tension was used to fit a model surface to the log thickness data (Inoue 1986; Supplementary S3). The FORTRAN code, developed by Inoue (1986) and modified by Engwell et al. (2015), outputs a gridded dataset across a specified x-y domain. This dataset was then processed in $\mathrm{R}$ using the 'raster', 'ggplot2' and 'rgal' packages to produce contoured plots of thickness (isopach maps).

\section{Erupted volume calculations}

From the spline fitted isopachs, the volume of distal Mazama tephra deposit was determined by fitting an exponential thickness decay to a plot of thickness versus square root isopach area (Pyle 1989). The same method was applied to previously published isopachs for comparison (Fig. 1).

The resulting log thickness versus square root area data was fit using 'AshCalc', a python tool for calculating erupted volumes (Daggitt et al. 2014). The exponential model assumes
Fig. 3 Field photographs of selected sites described in this study. a Tephra pit at Mount Bachelor (site 46). Star symbols reflect sampling sites. The tephra sequence records the climatic pumice fall and an upper finegrained unit which has been interpreted as fine fallout associated with the ignimbrite phase (co-ig ash). The top mixed layer was dominantly soil but contained occasional pumice clasts. b Mazama tephra reworked at the surface near Prineville reservoir (site 50). c A reversely graded, discontinuous layer of Mazama tephra near Mitchell, Oregon (site 55). d A 70-cm-thick layer of Mazama tephra at Juniper Canyon (site 80) on top of alluvial fan deposits. e Dune-like discontinuous deposit of Mazama tephra at Spring Gulch (site 81). f $3 \mathrm{~m}$ lens of remobilised Mazama tephra at Pole Bridge on top of alluvial deposits (site 69). g Zoom on remobilised Mazama at site 69 showing absence of sedimentary structures
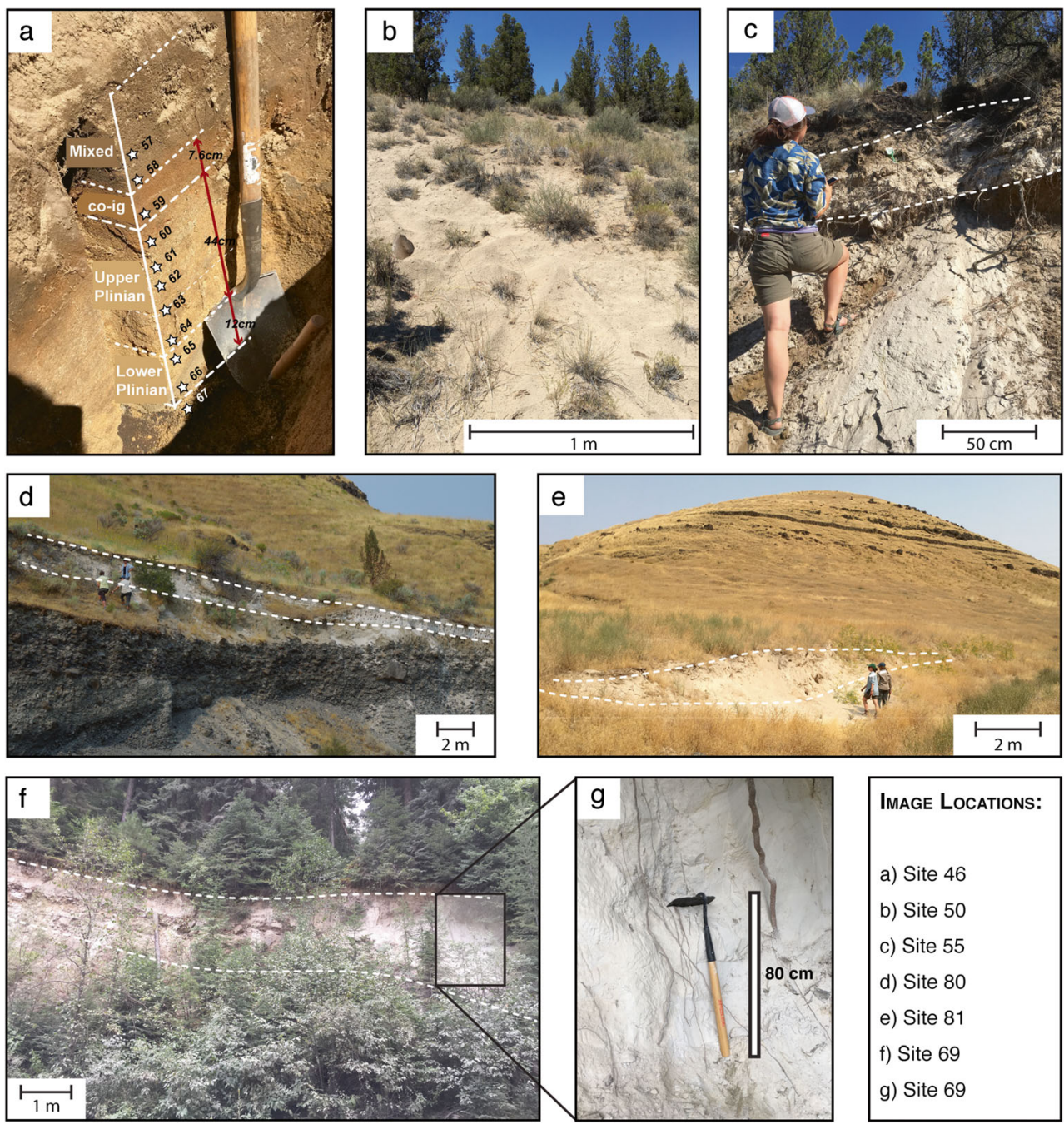
that tephra thickness can be described as a simple exponential decay away from the point of maximum thickness (Pyle 1989). For large and/or complex deposits, this exponential relationship breaks down and typically log thickness versus square root area plots are better described by multi-segment exponential decays (Pyle 1989; Fierstein and Nathenson 1992). In this work, we combine the distal isopachs with the spline isopachs of the proximal data (Young 1990) and fit multi-segment exponential decays using 'AshCalc' (Daggitt et al. 2014).

\section{Results}

The information amassed for each Mazama tephra locality and new field site is available in the database of tephra localities (Supplementary S1). The map in Fig. 2 shows all distal (> $100 \mathrm{~km}$ ) localities in the database. Each thickness measurement has been classed as either 'primary', 'secondary' or 'mixed' based on the information available in the original reference, field observations and drainage analysis. Where there was no description or insufficient data, the locality was left as 'unclassified'.

\section{Identifying remobilisation}

Thicknesses were classified as 'primary' where the measured thickness likely records the initial tephra thickness immediately after deposition. For example, site 46 (Fig. 3a) has been confidently classified as primary due to the well-preserved internal stratigraphy and topsoil development. Another primary site visited, site 73, preserves $30 \mathrm{~cm}$ of fine Mazama tephra with a sharp basal contact and well-developed topsoil. The locality is situated on a major drainage divide between the Snake River to the east and the John Day and Columbia Rivers to the west; therefore, we infer that the deposit at this site provides a minimum estimate of the primary fall deposit thickness, as no tephra has been remobilised from upslope (see Supplementary S2).

Thicknesses are considered 'secondary' if there is evidence for remobilisation such as slumping or bioturbation. An example from the literature is the $30 \mathrm{~cm}$ of Mazama tephra at site 174, Rockslide Lake in British Columbia, which contains multiple layers of Mazama tephra and has surrounding radiocarbon dates considerably younger than the eruptive date (Foit et al. 2004). A number of the sites are classed as secondary based on their field characteristics (Fig. 3b-g). Observations at site 80 (Fig. 3d) suggest that the $70 \mathrm{~cm}$ of the Mazama tephra overlying alluvial deposits has been remobilised (Sweeney et al. 2005; this study). Similarly, site 69 (Fig. 3f) records $>3 \mathrm{~m}$ of overthickened Mazama tephra (Carson and Pogue 1996; this study). Analysis of the upstream drainage (Supplementary S2) shows that, unlike site 73, there is substantial upstream drainage area for sites 69 and 80 which likely explains the overthickening.

'Mixed' thickness localities include both primary and secondary ash deposits. For example, the Mazama tephra at site 230 along the South Saskatchewan River has a sharp basal contact but is overlain by remobilised tephra that grades into the overlying sediment, which was included in the thickness reported (David 1970). Some sites where no thickness has been recorded were still classified based on the description of the stratigraphy.

Plotting log thickness against distance from source (Fig. 4) highlights the anomalous thickness values that have been classed as secondary and mixed. Typically, non-primary deposits tend to be thicker than the primary deposits at the same distance from source. The scatter in the thickness measurements with distance also reflects the scarcity of measurements that are on-axis, particularly $>500 \mathrm{~km}$ from source.

The grain size distributions (GSDs) of the ash samples collected for this study (Fig. 5) show that all the ash analysed from sites $>450 \mathrm{~km}$ from source is finer than $1 \mathrm{~mm}$. All the samples display a unimodal distribution with a mode between
Fig. 4 Log tephra thickness $(\mathrm{cm})$ versus true distance from source $(\mathrm{km})$. The solid line is a twosegment exponential fit to all the primary data and the dashed line is a two-segment fit to primary data $<200 \mathrm{~km}$ off-axis

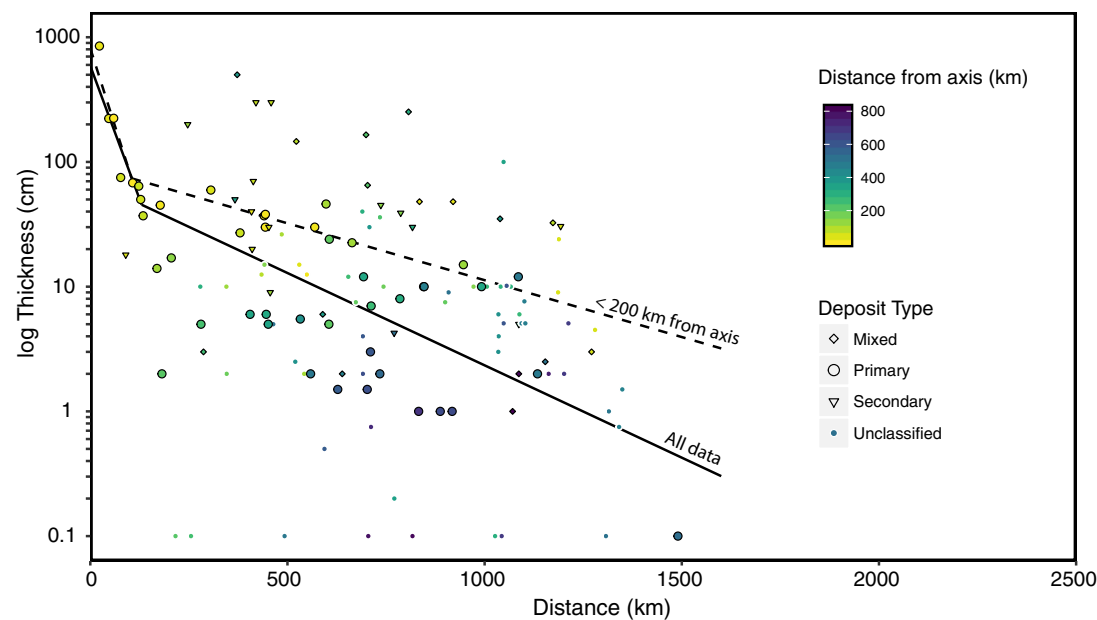




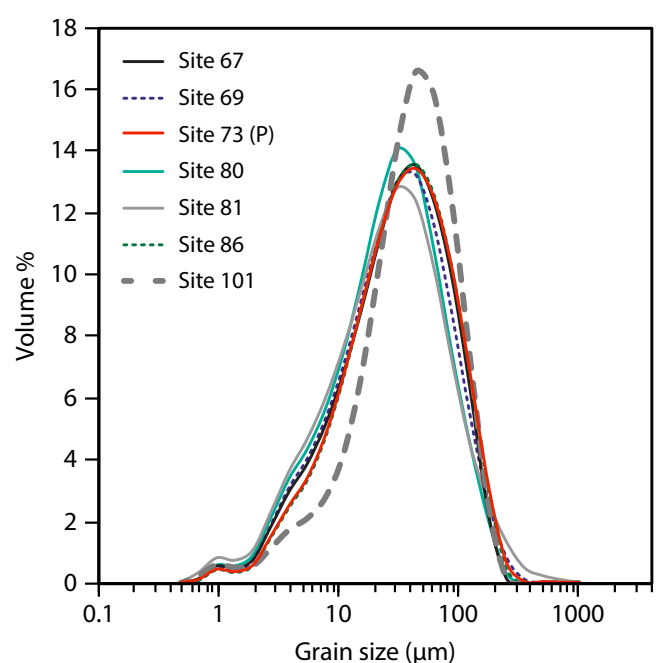

Fig. 5 Grain size distribution of distal samples. Site 73 (red) is the only primary (not remobilised) sample

38 and $54 \mu \mathrm{m}(4.8-4.3 \varphi)$ and median (Md) grain size of 33$49 \mu \mathrm{m}(4.9-4.4 \varphi)$. The sorting $(\sigma)$ of all samples is $\sim 1.5$ and the distributions are fine(negatively) skewed. The coarsest sample, with a median grain size of $49 \mu \mathrm{m}$, is from site 101 where the tephra had been excavated by a badger, which likely caused the fines to be lofted away explaining the fines depletion. The GSD from site 73, a primary tephra locality, overlaps with all other (remobilised) deposits.

\section{Cubic B-spline isopachs}

The cubic B-spline method was applied to the primary thickness data ( $n=45$, where $n$ is the number of measurements; Fig. 6a). Visually, the isopachs generated for the modelled thickness surface are similar to the published isopachs in terms of the dominant dispersal direction (Figs. 1 and 6), as forced by the inferred upwind thicknesses (Supplementary S3). However, even with the (inferred) upwind thicknesses, the spline isopachs do not match the tightness of the published upwind isopachs. Based on the lack of real upwind thickness data (SE of Crater Lake), we cannot assess whether the spline or published isopachs best represent the decay of thickness with distance in the upwind direction. Another difference between the spline and published isopachs is the extent and value of the thickest isopach. Specifically, the published isopachs show $30 \mathrm{~cm}$ of tephra reaching $\sim 500 \mathrm{~km}$ downwind (Fig. $1 \mathrm{~b}-\mathrm{d}$ ), but this is not reflected in the cubic B-spline isopachs (Fig. 6a). The spline isopach that best matches the published $30 \mathrm{~cm}$ isopachs is $20 \mathrm{~cm}$ thick. Whilst there are some important differences between the published and spline isopachs, the overall shape agrees with Lidstrom (1971) and Young (1990). In particular, along the main dispersal axis the extent of the $5 \mathrm{~cm}$ isopach is in close agreement.

The cubic B-spline method was also applied to all the thickness data $(n=138)$ recorded in the database (Fig. $6 \mathrm{~b})$, including thickness measurements that have been classed as secondary, mixed and unclassified. The resulting isopachs record a more complex and convolute distribution of tephra thickness. In particular, the spline isopachs highlight an area of overthickening in north-eastern Washington, which broadly overlaps with the area designated as 'distal thickening' by Matz (1987). Another key difference between the published and spline isopachs is the $1 \mathrm{~cm}$ isopach. All of the published isopach maps include a 1-cm limit. However, the spline interpolation method had insufficient data to draw a closed contour of $1 \mathrm{~cm}$.

The cubic B-spline isopachs of the proximal data from Young (1990) are shown in Fig. 6c. The overall distribution of thickness is close to his hand-drawn isopachs, although, as with the distal spline isopachs, the upwind decay of thickness is much tighter in the hand-drawn isopachs. A south-east lobe in the cubic spline isopachs (Fig. 6c) corresponds to a mapped
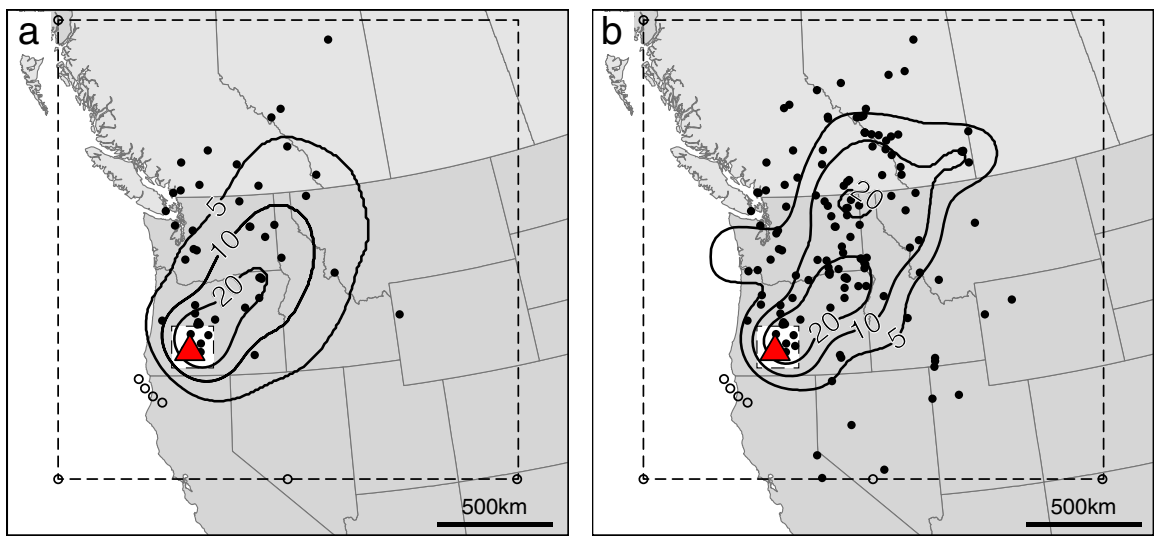

Fig. 6 Cubic B-spline isopachs. The thickness measurements used to generate each isopach are shown as filled black circles, the inferred thicknesses are plotted as open circles and the isopach thickness is in $\mathrm{cm}$. a Primary thickness data and spline isopachs. b All thickness data and (mixed) spline isopachs. c Spline isopachs of proximal Young (1990) data. In $\mathbf{a}$ and $\mathbf{b}$, the domain over which the spline interpolation was performed is shown by the dashed box and the proximal domain is a filled white square 
SE lobe in the lower pumice unit of the Plinian fall that was observed and interpreted by Williams (1942), Lidstrom (1971), and Young (1990) to correspond to a different wind direction and or plume height at the onset of the eruption.

The goodness of fit of the spline surface to the thickness data is output as a root mean square (RMS) residual (see Table 2). Although the RMS value quantifies the fit of the whole spline surface, we are interested in the difference between the modelled and measured thicknesses at individual localities. To assess this difference, we calculate a percentage error between the measured thickness and modelled thickness at each locality:

\%error $=\frac{\mid \text { modelled thickness }- \text { measured thickness } \mid}{\text { modelled thickness }} \times 100$

Importantly, in Eq. 1, we divide the absolute difference by the modelled thickness because we want to highlight localities where the measured value deviates strongly from the spline predicted value. We expect the spline surface to poorly match thick proximal sites due to the majority of the data fitted with the cubic B-splines being thinner distal data. For example, at a proximal locality (site 26), the measured tephra thickness is $233 \mathrm{~cm}$, but the spline surface predicts $38 \mathrm{~cm}$ which we calculate as a $486 \%$ error. Whilst the fit appears poor to these few proximal sites, they were necessary to include in the fitting of the cubic B-spline model to locate the area of maximum thickness (Fig. 7a). For the mixed spline isopachs (Fig. 7b), the RMS residual and number of points with $>400 \%$ difference between the spline and measured thickness is greater than in Fig. 7a because the spline fitting has smoothed highly irregular data. Comparing the measured thicknesses of secondary and mixed sites to the primary spline surface (Fig. 7c) clearly highlights areas of overthickening (secondary and mixed deposits), where the percentage difference is typically $>400 \%$. Comparing the unclassified thicknesses to the primary spline surface (Fig. 7d) shows that 43 unclassified thicknesses are within $100 \%$ of the value predicted by the spline surface.

\section{Volume calculations}

The volume of the distal Mazama tephra calculated from the individual isopach maps in Figs. 1 and 6 are shown in Table 2. For Fig. 6b, the total area enclosed by the thickest isopach is the summation of the areas enclosed by the two closed $20 \mathrm{~cm}$ contours. The volumes calculated from the primary and mixed spline isopachs are $134 \mathrm{~km}^{3}$ and $161 \mathrm{~km}^{3}$ respectively. The mixed spline isopachs thus suggest a $\sim 30-\mathrm{km}^{3}$ increase in volume compared to the isopachs drawn using only the primary data. The largest calculated volume is $242 \mathrm{~km}^{3}$, which includes the isopachs that show a zone of distal thickening and a large 1-cm isopach (Fig. 1c; Matz 1987). The smallest volume $\left(131 \mathrm{~km}^{3}\right)$ was calculated from the distal Young (1990) isopachs. Importantly, all of the volumes calculated using the distal data alone are minima, as they do not include the volume in the thick proximal fallout.

The volumes in Table 2 calculated using both the proximal (Young 1990) and distal data were fit using one-, two- and three-segment exponential fits, as shown in Fig. 8. Using two exponential segments produces a better fit to the proximal and medial data for all of the isopach combinations compared to the single segment exponential decay which underestimates the thickness close to the vent and overestimates intermediate thicknesses. We also tested three-segment exponential fits, but conclude that they 'overfit' the data, as in most cases there are only two points controlling each exponential segment.

\section{Discussion}

\section{Sources of variability in tephra thickness measurements}

The amalgamation of $>250$ Mazama tephra occurrences highlights the wide range of disciplines that make use of the tephra layer from volcanology (Westgate and Dreimanis 1967; Mullineaux 1974) to archaeology (Kittleman 1973;

Table 2 Calculated volumes from spline and published isopachs

\begin{tabular}{|c|c|c|c|c|c|c|c|}
\hline Isopachs & $\begin{array}{l}\text { Number of } \\
\text { measurements }(n)\end{array}$ & $\begin{array}{l}\text { Number of distal } \\
\text { isopachs (thicknesses } \\
\text { in } \mathrm{cm} \text { ) }\end{array}$ & $\begin{array}{l}\text { Distal volume } \\
\text { only }\left(\mathrm{km}^{3}\right)^{\mathrm{a}}\end{array}$ & $\begin{array}{l}\text { RMS residual } \\
\text { of spline fit }\end{array}$ & $\begin{array}{l}\text { One-segment fit } \\
\text { volume }\left(\mathrm{km}^{3}\right)^{\mathrm{b}}\end{array}$ & $\begin{array}{l}\text { Two-segment fit } \\
\text { volume }\left(\mathrm{km}^{3}\right)^{\mathrm{b}}\end{array}$ & $\begin{array}{l}\text { Three-segment fit } \\
\text { volume }\left(\mathrm{km}^{3}\right)^{\mathrm{b}}\end{array}$ \\
\hline Primary spline & 45 & $3(5,10,20)$ & 134 & 0.417 & 163 & 148 & 163 \\
\hline Mixed spline & 138 & $3(5,10,20)$ & 161 & 0.542 & 202 & 172 & 183 \\
\hline Lidstrom (1971) & 20 & $4(1,5,15,30)$ & 153 & - & 227 & 163 & 170 \\
\hline Young (1990) & 25 & $3(1,5,30)$ & 131 & - & 195 & 139 & 144 \\
\hline Matz (1987) & 54 & $5(1,5,10,15,30)$ & 242 & - & 336 & 252 & 249 \\
\hline
\end{tabular}

${ }^{\mathrm{a}}$ Using only distal isopach data

${ }^{\mathrm{b}}$ Combining distal and proximal (Young 1990) isopach data 
Fig. 7 Percentage difference between the actual thickness measurements and the spline interpolated thicknesses. Isopach thicknesses are 20, 10 and $5 \mathrm{~cm}$. a Primary thickness only. b Mixed spline thicknesses. c Difference between mixed thicknesses and primary spline surface. $\mathbf{d}$ Difference between primary and unclassified thicknesses and primary spline surface
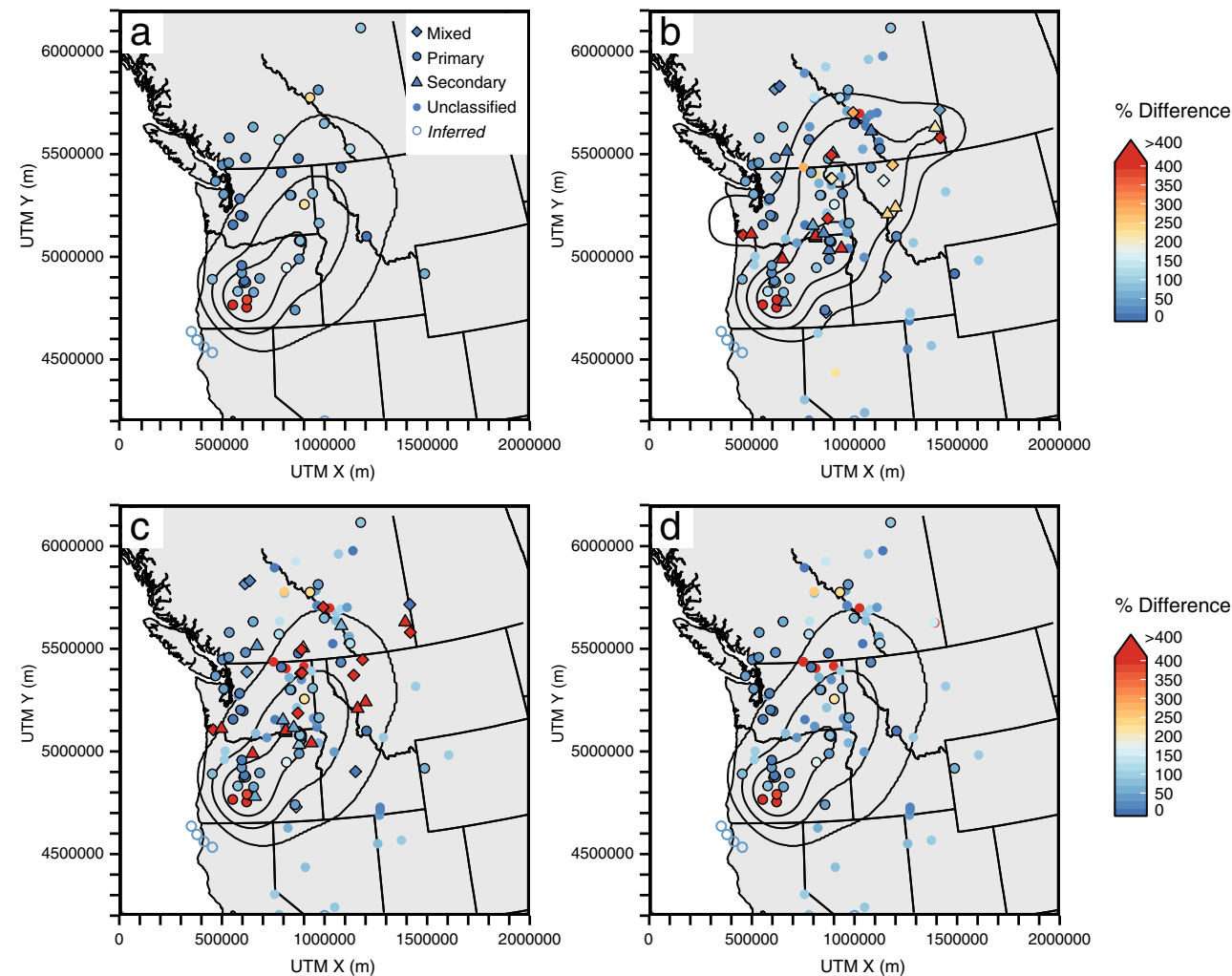

McFarland 1989). The multidisciplinary use of the Mazama tephra has resulted in different methods of data collection and variable data quality. However, this alone cannot explain the extreme variations in tephra thickness data (Figs. 2 and 4). The large variability of tephra thickness across the deposit also reflects the extensive remobilisation of the distal Mazama tephra, as the material has been eroded and redeposited over the past $\sim 7700$ years. Despite the paucity of primary distal
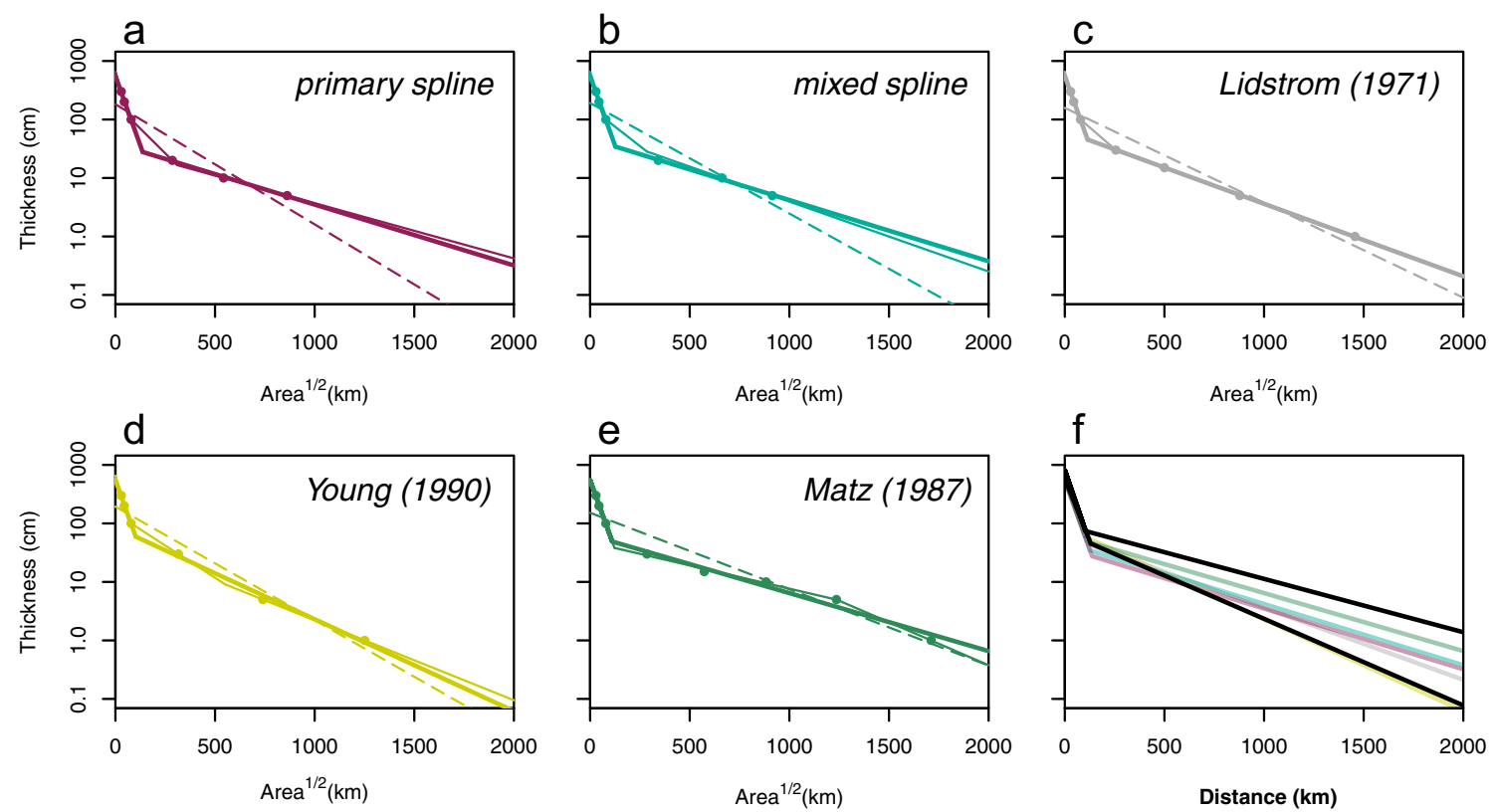

Fig. 8 Square root area versus log thickness plots for proximal and distal Mazama isopachs. a-e Dashed line shows single segment fit, thick line shows two-segment fit and thin line shows three-segment fit. Corresponding volume estimates can be found in Table 2. All proximal

a Primary spline isopachs. b Mixed spline isopachs. c Lidstrom (1971). d Young (1990). e Matz (1987). f Two-segment exponential fits to log thickness versus true distance data from Fig. 4 overlain on two-segment fits from a to $\mathbf{e}$ 
Mazama tephra localities, detailed reporting and publication of all tephra sites is important as remobilised localities provide a record of tephra deposition close to that location.

Direct field observations of remobilised deposits identify common features of non-primary Mazama tephra, such as discontinuous beds, lens and fan-shaped outcrops and the co-occurrence with alluvial deposits (Fig. 3). Where we observed remobilised Mazama tephra, however, there were no obvious sedimentary structures; this differs from the remobilised YTT deposits which contain fine scale crossbeds (Gatti et al. 2013). The remobilised YTT also exhibits different GSDs compared to the primary YTT (Gatti et al. 2011, 2013); in contrast, the GSD of the remobilised and primary Mazama tephra are nearly identical, at least $\sim 150$ $500 \mathrm{~km}$ from source (Fig. 5). Therefore, without broad deposit context, distinguishing the remobilised Mazama tephra deposits from primary Mazama tephra is difficult. The lack of sedimentary structures, and seemingly unaltered GSD, suggests that the remobilised distal samples have not experienced significant contamination from background sediments, or hydrodynamic sorting, even when found on top of alluvial deposits, implicating water in the remobilisation process. This is in contrast to the prominent sedimentary structures in remobilised YTT that are clearly the result of transport by water (Gatti et al. 2013). We hypothesise that downslope remobilisation of Mazama tephra occurred en-masse with minimal water entrainment and shortly after the primary deposition, such that little foreign material was incorporated and no sedimentary structures were developed.

During the mid-Holocene $(\sim 8-5 \mathrm{ka})$ North America was slightly warmer and drier than present (Dean et al. 1996; Thompson et al. 2016) and reconstructions of the vegetation cover (Fig. 9; Adams et al. 1997) suggest that most of the Mazama tephra was deposited in a semi-desert to tundra dominated environment. This supports our interpretation that the downslope processes that led to the substantially overthickened deposits (Fig. 3) could have been relatively dry. However, pollen suggest that the Mazama eruption occurred in northern hemisphere autumn (Mehringer et al. 1977). This could have resulted in snow melt the following spring remobilising the deposits in some areas (Manville et al. 2000) and the unimodal grain size distribution of the distal tephra (Fig. 5) may be the reason for the absence of obvious sedimentary structures. As such, the processes that lead to extreme overthickening ( $3 \mathrm{~m}$ from $\sim 30 \mathrm{~cm}$ primary fall at site 69) require further study.

To avoid the challenges of redeposited terrestrial tephra deposits, numerous studies have used lake sediments to
Fig. 9 Mazama tephra distribution in relation to palaeovegetation cover.

Vegetation zone limits are from Adams et al. (1997)

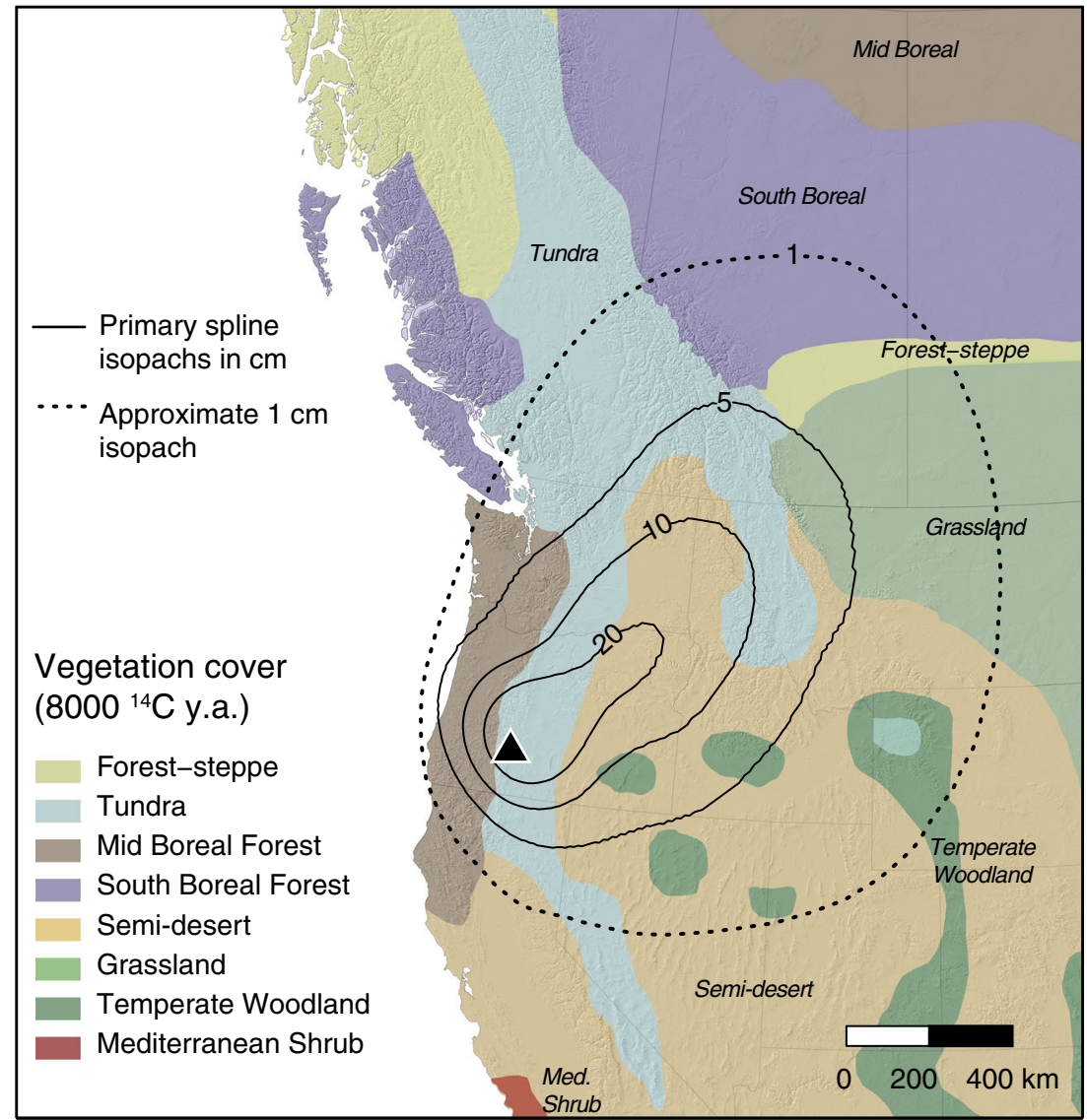


reconstruct volcanic histories as lake cores can provide excellent records of tephra stratigraphy (e.g. Lowe et al. 1980; Hopkins et al. 2015; Fontijn et al. 2016; McNamara et al. 2019). However, we find that lake cores, as with land sections, do not always provide reliable records of tephra thickness. Remobilised tephra in lake cores can be identified by diffuse upper or lower contacts with the background sediments, altered GSDs and anomalous radiocarbon dates surrounding the layer (Hopkins et al. 2015). For example, Swiftcurrent Lake (site 150) in Montana contains $48 \mathrm{~cm}$ of Mazama tephra but with up to $25 \%$ clastic contamination (MacGregor et al. 2011), suggesting the layer measured was a mixture of primary and reworked material. Unfortunately, many of the lake core localities lack detailed observations of the tephra layer making it difficult to confidently classify the tephra as remobilised or primary.

A number of factors can affect the thickness of tephra recorded in lake cores, including the vegetation and steepness of the surrounding hillslopes (Dugmore et al. 2018), catchment size (Supplementary S2), lake depth, aeolian transport, the position of major inlets relative to the coring sites and the background sedimentation (McNamara et al. 2018). Factors independent of the lake setting may also influence the preservation of tephra in lake cores. For example, the rate of tephra deposition and the quantity of accumulated tephra will influence how the tephra is transported from the lake surface to the lake bottom (Engwell et al. 2014; McNamara et al. 2019). The density and grain size of the tephra could be another external factor affecting tephra preservation in lakes. The distal Mazama tephra is fines dominated $(\sim 32-63 \mu \mathrm{m}$; Fig. 5) which may make it more susceptible to syn-deposition remobilisation as the slower settling velocities will mean it has a longer residence time in the water column. Furthermore, once it has reached the lake bottom, finegrained tephra experience additional remobilisation by lake bottom currents and bioturbation (Dashtgard et al. 2008).

Tephra thicknesses recorded in both lake and terrestrial settings may also have been influenced by wind remobilisation. The modal grain size of the distal Mazama tephra (Fig. 5) falls within the range measured for resuspended modern ash in Iceland and Argentina (Liu et al. 2014; Panebianco et al. 2017) and is also similar to (windtransported) loess (Sun et al. 2004). Semi-desert and tundra environments, which we infer a substantial proportion of the tephra was deposited in (Fig. 9), provide the ideal dry and windy conditions for tephra resuspension. Wind remobilisation could thin the deposit in some places but could also explain overthickening in other sites. For example, at Marys Pond, Montana (site 102; Foit et al. 1993), the small glacial lake must have had an input of Mazama tephra other than purely upstream to explain the accumulation of 9-90 cm of tephra $>700 \mathrm{~km}$ from source. Other windblown particulates, such as loess, are known to accumulate in lakes (Pye 1995); therefore, windblown tephra may help explain some overthickened lake deposits.

Understanding mechanisms that remobilise tephra after a large eruption are crucial for anticipating post-eruptive hazards. Ash resuspension, for example, has closed airports (Hadley et al. 2004) and could pose hazards to human health (Horwell and Baxter 2006; Thorsteinsson et al. 2012). Resuspension events are a persistent hazard in Alaska over 100 years after the magnitude 6.5 Novarupta (Katmai) eruption in 1912 (Hadley et al. 2004) and it is likely that the Mazama tephra $(M>7)$ posed resuspension hazards over similar time scales or longer. Archaeological records provide evidence for long term ash remobilisation, revealing that communities abandoned parts of the north-western Plains (modern Wyoming, Montana, North and South Dakota, southern Alberta Saskatchewan and Manitoba) following the Mazama eruption and only returned permanently after 500 years (Oetelaar and Beaudoin 2016).

\section{Validity of isopachs for large eruptions}

The published isopachs for the distal Mazama tephra (Fig. 1) show the challenges in creating isopachs for large and older tephra deposits. Our study shows that the isopach variability derives from overthickening, sparse coverage and different environments of deposition (Figs. 2, 3 and 4). This raises the question of whether isopach maps are an appropriate way to present thickness data for large deposits, or if the uncertainties and limitations invalidate this approach. The disadvantages of hand-drawn isopachs have been discussed (Klawonn et al. 2014; Engwell et al. 2015), whilst acknowledging the value of intrinsic knowledge of the authors, which may not be possible to quantify or transfer by means other than hand-drawn isopachs. However, it is still important to clearly document the data used to construct the isopachs in a best effort to transfer this knowledge. As Fig. 1 shows, often the data are poorly documented and are therefore unusable except to determine the areal extent of tephra coverage.

Alternatively, studies of large and poorly documented deposits may report thickness against true distance from source (e.g. Campanian, Engwell et al. 2014; Toba, Gatti and Oppenheimer 2012; Taupo, Matthews et al. 2012). The equivalent plot of the Mazama thickness data in Fig. 4 shows the value of this approach. Here the large scatter of thickness data at the same distance from source reflects both the distance from the main dispersal axis and the inclusion of nonprimary thickness measurements. Using the data in this form for volume calculations comes with caveats (see below and Supplementary S4); however, qualitatively comparing the decay of thickness with distance between large tephra deposits provides a means of contrasting the magnitudes of different eruptions without the need to draw isopachs. We demonstrate 
this in Fig. 10, where we compare exponential fits to the distal thickness data for the Campanian (Engwell et al. 2014), Rangitawa (Taupo; Matthews et al. 2012), YTT (Matthews et al. 2012) and Mazama eruptions. Whilst the data exhibit substantial scatter due to the reasons previously discussed, the simple exponential fits highlight the different thinning trends of 'super-eruptions' $(M>8)$ and magnitude $\sim 7$ eruptions such as the Mazama and Campanian.

\section{Spline fitted isopachs}

To overcome the disadvantages of hand-drawn isopachs, we applied a spline interpolation method (Engwell et al. 2015) to the distal and proximal thickness data (Fig. 6). This method generates reproducible isopachs of the distal Mazama tephra with reduced subjectivity. However, the spline fitting still requires user input, therefore necessitating prior knowledge of the deposit. For example, fitting the cubic B-spline to the raw primary thickness data required inferred upwind thicknesses to characterise the asymmetry of the deposit (Supplementary S3). This user input can only be avoided entirely when the thickness dataset is spatially dense, with zero values delimiting the edge of the deposit (e.g. Mount Saint Helens, 1980; Sarna-Wojcicki et al. 1981; Engwell et al. 2015). Fitting the cubic B-spline model also requires a choice of the fitting parameters: roughness, tension, area divisions and weightings (Supplementary S3). For this study, we followed the guidelines of Engwell et al. (2015) and found the values that best visually recreated the expected dispersal; however, this introduces another area of subjectivity.

Irrespective of the limitations of the spline method, there are benefits to using models to generate isopachs. Notably, the same isopachs can now be reproduced given the same thickness dataset and model parameters regardless of user bias or experience which cannot be said for hand-drawn isopachs (Klawonn et al. 2014). The spline fit does not recreate the exact fallout of the Mazama tephra, as it involves no physical processes relating to ash dispersal and transport, but it generates a 'model' tephra surface from which anomalous thicknesses and unusual deposition can be highlighted (Fig. 7). Figure $7 \mathrm{c}$ shows the correlation between the percentage difference and the thickness classification. Additionally, Fig. 7d shows that this approach could be used to make best estimates of otherwise 'unclassified' localities which could inform future field studies of primary tephra localities. Another benefit of using the spline fitting approach is the capacity to include non-primary thicknesses to explore the sensitivity of isopach construction to these measurements (Fig. 6b).

\section{Estimating the erupted volume from large tephra deposits}

The bulk erupted volumes of the distal Mazama tephra calculated from published and spline isopachs using an exponential fit range from 131 to $242 \mathrm{~km}^{3}$ (Table 2). The range in estimates arises from the inclusion of non-primary thicknesses (Fig. 6b) and convolute published isopachs (Fig. 1c; Matz 1987). Including non-primary, overthickened thickness measurements in isopach construction is useful for highlighting areas of tephra remobilisation. However, using isopachs that include overthickened data to estimate erupted volumes is problematic as this negates the assumption of deposit thinning with increasing distance from source, which is fundamental to the methods used to estimate volumes from isopach maps (Pyle 1989; Fierstein and Nathenson 1992). For this reason, direct integration of the volume below the spline surface may provide a better way to estimate volume from non-primary isopachs (Supplementary S4). However, the spline fit
Fig. 10 Comparing the exponential decay of distal tephra thickness with distance from large magnitude eruptions. Younger Toba Tuff(YTT), Campanian and Mazama magnitude values (M) are taken from the LaMEVE database, (VOLGRIPA; www.bgs. ac.uk/vogripa/view/controller. cfc?method=lameve) and Rangitawa $\mathrm{M}$ is assuming DRE > $1500 \mathrm{~km}^{3}$ (Matthews et al. 2012)

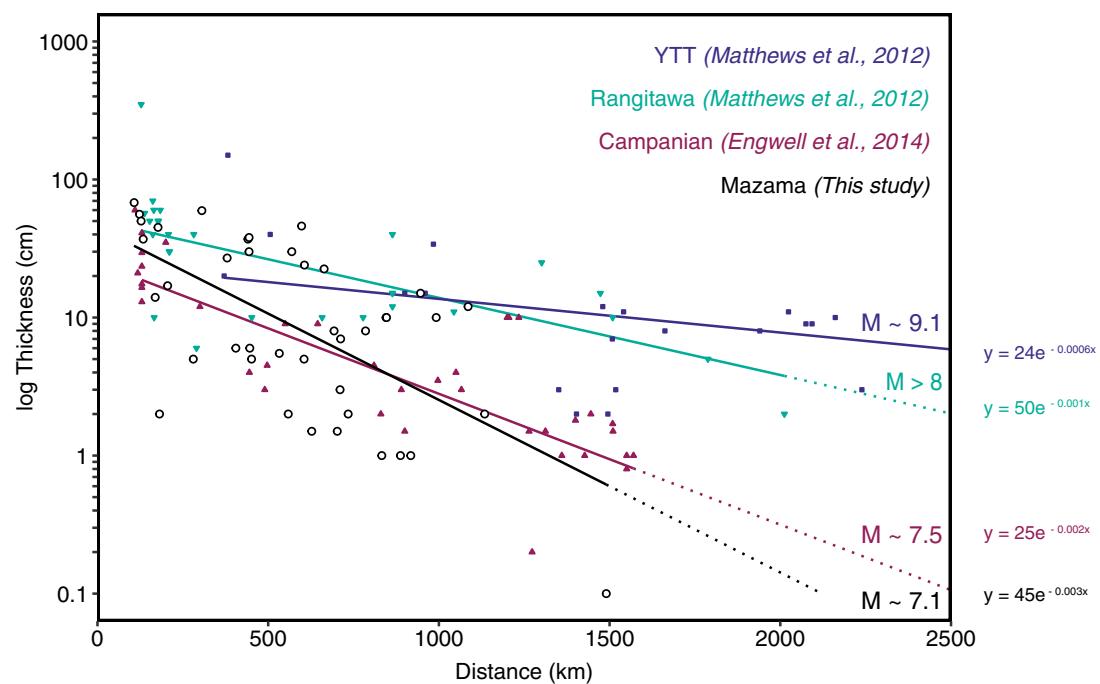


underestimates the thickness at source and the integration range is limited by the thinnest isopach; this method provides only volume minima. For these reasons, we do not use the convolute (Matz 1987; Fig. 1c) and mixed spline isopachs (Fig. 6b) to estimate the total erupted volume of the Mazama tephra. Whilst the range in estimates remains significant (distal only 131-153 km $\mathrm{km}^{3}$; Table 2), large uncertainties on erupted volumes are expected for large eruptions.

Combining the primary distal spline isopachs (Fig. 6a) and the proximal spline isopachs (Fig. 6c) gives the best estimate of $148 \mathrm{~km}^{3}$ bulk erupted volume. When added to the $\sim 29 \mathrm{~km}^{3}$ assumed to be in the ignimbrite (Williams 1942), we estimate a total erupted volume of $\sim 176 \mathrm{~km}^{3}$ which is $\sim 20 \mathrm{~km}^{3}$ greater than the estimates in Table 1. To convert this to a dense-rock equivalent (DRE) volume, we assign average densities to the three portions of the deposit and use $2200 \mathrm{~kg} \mathrm{~m}^{-3}$ as the bulk density of the magma (Lidstrom 1971; Young 1990). For the proximal deposit, we use an average deposit density of $500 \mathrm{~kg} \mathrm{~m}^{-3}$, taking into account average pumice densities (Young 1990) and packing density. We measured a bulk density of $700 \mathrm{~kg} \mathrm{~m}^{-3}$ for the distal ash, which is in agreement with the value used by Lidstrom (1971), Bacon (1983) and Young (1990), with the low density likely reflecting the micro-vesicularity of the fine ash. For the ignimbrite we use $1200 \mathrm{~kg} \mathrm{~m}^{-3}$, the higher density reflecting the large lithic component in the ignimbrite flows (Bacon 1983). Using this density distribution and the relative proportion of volume in the proximal $\left(19 \mathrm{~km}^{3}\right)$ and distal $\left(129 \mathrm{~km}^{3}\right)$ segments, we calculate a DRE volume of $\sim 61 \mathrm{~km}^{3}$ and calculate an eruption magnitude of $7.1\left(M=\log _{10}(\mathrm{DRE} \times 2200)-7\right.$; Pyle 2000). This value is in agreement with DRE estimates by Lidstrom (1971) and Bacon (1983) and is less than the caldera and edifice volume estimate by Bacon and Lanphere (2006) allowing for the volume contained in collapse deposits and pre-caldera forming eruptions (Table 1).

\section{Conclusions}

Estimating the eruptive volume and magnitude of prehistoric large magnitude eruptions is vital to interpreting the hazards posed by these eruptions. However, the tephra deposits required to estimate parameters, such as eruptive volume, are often poorly preserved and exhibit low sampling density and diverse data quality, especially at large distances from source $(>100 \mathrm{~km})$. These limitations are encountered when interpreting the distal Mazama tephra. We combined an extensive literature search, field observations and new methods of interpolation and data manipulation, to develop an extensive record of Mazama tephra occurrences (Supplementary S1). Using the compilation of primary tephra sites, we constructed new reproducible isopachs of the deposit and revised the bulk erupted volume estimate to $\sim 176 \mathrm{~km}^{3}$, including the ignimbrite volume. The new isopach map (Fig. 9) provides a modelled thickness distribution which broadly agrees with past hand-drawn isopachs and are a resource that can be used to inform future field studies. Specifically, further work is needed to constrain the upwind deposit and the limits of the distal tephra, for example the limit of the $1 \mathrm{~cm}$ isopach which has only been approximated (Fig. 9). This will improve our volume estimates as well as our understanding of the spatial footprint of hazards from the primary tephra fallout during large caldera forming eruptions.

We use our compilation of Mazama tephra occurrences and isopach maps to highlight areas where the Mazama tephra has been remobilised and overthickened and show that incorporating non-primary thicknesses dramatically influences the isopachs and the bulk erupted volume estimates. However, we emphasise that the reporting of all tephra sites is important as they are still a record of deposition at a specific location, even if the thickness cannot be used in isopach construction. Furthermore, understanding the mechanisms and conditions that encourage tephra remobilisation is crucial for interpreting the post-eruptive hazards posed by a Mazama-like eruption as they have the potential to have long-lasting effects (100+ years) over large areas (millions of $\mathrm{km}^{2}$ ).

Acknowledgements H.M.B is supported by a NERC GW4+ Doctoral Training Partnership studentship from the Natural Environment Research Council (NERC; NE/L002434/1) with additional support from the British Geological Survey. S.L.E. publishes with permission of the CEO, British Geological Survey. We would like to acknowledge the numerous researchers whose fieldwork and analysis contributed to the Mazama Locality Database. Thanks to Joanne Egan and John Westgate for sharing their databases of Mazama tephra localities that enabled this study to progress. Further thanks go to Colin Long, Britta Jensen, Mark Shapley and Jack Oviatt who shared their knowledge of Mazama tephra localities with us directly. We also extend a broad thanks to the attendees of the INTAV conference in Romania 2018, where this work was presented initiating many helpful conversations. Fieldwork was carried out with help from Bob Carson, Kirsten Nicolyasen, Danielle McKay and Emily Gottesfeld who are greatly acknowledged. Finally, we thank David Pyle and Stephen Self for their useful reviews, which improved the paper, and associate editor P.-S. Ross for quick and helpful handling.

Open Access This article is licensed under a Creative Commons Attribution 4.0 International License, which permits use, sharing, adaptation, distribution and reproduction in any medium or format, as long as you give appropriate credit to the original author(s) and the source, provide a link to the Creative Commons licence, and indicate if changes were made. The images or other third party material in this article are included in the article's Creative Commons licence, unless indicated otherwise in a credit line to the material. If material is not included in the article's Creative Commons licence and your intended use is not permitted by statutory regulation or exceeds the permitted use, you will need to obtain permission directly from the copyright holder. To view a copy of this licence, visit http://creativecommons.org/licenses/by/4.0/. 


\section{References}

Adams J (1990) Paleoseismicity of the Cascadia Subduction Zone: evidence from turbidites off the Oregon-Washington Margin. Tectonics 9:569-583. https://doi.org/10.1029/TC009i004p00569

Adams J, Beaudoin A, Davis O, et al (1997) North America during the last 150,000 years. In: Global land environments since the last interglacial. https://www.esd.ornl.gov/projects/qen/nerc.html

Bacon CR (1983) Eruptive history of Mount Mazama and Crater Lake caldera, Cascade Range, U.S.A. J Volcanol Geotherm Res 18:57115. https://doi.org/10.1016/0377-0273(83)90004-5

Bacon CR, Druitt TH (1988) Compositional evolution of the zoned calcalkaline magma chamber of Mount Mazama, Crater Lake, Oregon. Contrib Mineral Petrol 98:224-256. https://doi.org/10. 1007/BF00402114

Bacon CR, Lanphere MA (2006) Eruptive history and geochronology of Mount Mazama and the Crater Lake region, Oregon. Geol Soc Am Bull 118:1331-1359. https://doi.org/10.1130/B25906.1

Biass S, Bonadonna C (2011) A quantitative uncertainty assessment of eruptive parameters derived from tephra deposits: the example of two large eruptions of Cotopaxi volcano, Ecuador. Bull Volcanol 73: 73-90. https://doi.org/10.1007/s00445-010-0404-5

Blong R, Enright N, Grasso P (2017) Preservation of thin tephra. J Appl Volcanol 6:10-15. https://doi.org/10.1186/s13617-017-0059-4

Blott SJ, Pye K (2001) GRADISTAT: a grain size distribution and statistics package for the analysis of unconsolidated sediments. Earth Surf Process Landf 26:1237-1248. https://doi.org/10.1002/esp.261

Bonadonna C, Costa A (2013) Plume height, volume, and classification of explosive volcanic eruptions based on the Weibull function. Bull Volcanol 75:742. https://doi.org/10.1007/s00445-013-0742-1

Bonadonna C, Ernst GGJ, Sparks RSJ (1998) Thickness variations and volume estimates of tephra fall deposits: the importance of particle Reynolds number. J Volcanol Geotherm Res 81:173-187. https:// doi.org/10.1016/S0377-0273(98)00007-9

Boygle J (1999) Variability of tephra in lake and catchment sediments, Svínavatn, Iceland. Glob Planet Chang 21:129-149. https://doi.org/ 10.1016/S0921-8181(99)00011-9

Burden RE, Chen L, Phillips JC (2013) A statistical method for determining the volume of volcanic fall deposits. Bull Volcanol 75:707. https://doi.org/10.1007/s00445-013-0707-4

Carey S, Sparks R (1986) Quantitative models of the fallout and dispersal of tephra from volcanic eruption columns. Bull Volcanol 48:109125

Carson RJ, Pogue KR (1996) Flood basalts and glacier floods: roadside geology of parts of Walla Walla, Franklin, and Columbia counties, Washington. Washington State Department of Natural Resources, Division of Geology and Earth Resources, Information Circular 90:47

Crosweller HS, Arora B, Brown SK et al (2012) Global database on large magnitude explosive volcanic eruptions (LaMEVE). J Appl Volcanol 1:4. https://doi.org/10.1186/2191-5040-1-4

Cutler NA, Streeter RT, Marple J, Shotter LR, Yeoh JS, Dugmore AJ (2018) Tephra transformations: variable preservation of tephra layers from two well-studied eruptions. Bull Volcanol 80:77-15. https://doi.org/10.1007/s00445-018-1251-z

Daggitt ML, Mather TA, Pyle DM, Page S (2014) AshCalc - a new tool for the comparison of the exponential, power-law and Weibull models of tephra deposition. J Appl Volcanol 3:7. https://doi.org/ 10.1186/2191-5040-3-7

Dashtgard SE, Gingras MK, Pemberton SG (2008) Grain-size controls on the occurrence of bioturbation. Palaeogeogr Palaeoclimatol Palaeoecol 257:224-243. https://doi.org/10.1016/j.palaeo.2007.10. 024

David PP (1970) Discovery of Mazama ash in Saskatchewan, Canada. Can J Earth Sci 7:1579-1583. https://doi.org/10.1139/e70-150
Dean WE, Ahlbrandt TS, Anderson RY, Platt Bradbury J (1996) Regional aridity in North America during the middle Holocene. The Holocene 6:145-155. https://doi.org/10.1177/095968369600600202

Druitt TH, Bacon CR (1986) Lithic breccia and ignimbrite erupted during the collapse of Crater Lake Caldera, Oregon. J Volcanol Geotherm Res 29:1-32. https://doi.org/10.1016/0377-0273(86)90038-7

Dugmore A, Streeter R, Cutler N (2018) The role of vegetation cover and slope angle in tephra layer preservation and implications for Quaternary tephrostratigraphy. Palaeogeogr Palaeoclimatol Palaeoecol 489:105-116. https://doi.org/10.1016/j.palaeo.2017.10. 002

Egan J, Staff R, Blackford J (2015) A high-precision age estimate of the Holocene Plinian eruption of Mount Mazama, Oregon, USA. The Holocene 25:1054-1067. https://doi.org/10.1177/ 0959683615576230

Engwell SL, Sparks RSJ, Aspinall WP (2013) Quantifying uncertainties in the measurement of tephra fall thickness. J Appl Volcanol 2:5. https://doi.org/10.1186/2191-5040-2-5

Engwell SL, Sparks RSJ, Carey S (2014) Physical characteristics of tephra layers in the deep sea realm: the Campanian ignimbrite eruption. Geol Soc Lond, Spec Publ 398:47-64. https://doi.org/10.1144/ SP398.7

Engwell SL, Aspinall WP, Sparks RSJ (2015) An objective method for the production of isopach maps and implications for the estimation of tephra deposit volumes and their uncertainties. Bull Volcanol 77: 61. https://doi.org/10.1007/s00445-015-0942-y

Eychenne J, Le Pennec J-L, Troncoso L et al (2012) Causes and consequences of bimodal grain-size distribution of tephra fall deposited during the August 2006 Tungurahua eruption (Ecuador). Bull Volcanol 74:187-205. https://doi.org/10.1007/s00445-011-0517-5

Fierstein J, Nathenson M (1992) Another look at the calculation of fallout tephra volumes. Bull Volcanol 54:156-167. https://doi.org/10.1007/ BF00278005

Foit FF, Mehringer PJ, Sheppard JC (1993) Age, distribution, and stratigraphy of Glacier Peak tephra in eastern Washington and western Montana, United States. Can J Earth Sci 30:535-552. https://doi. org/10.1139/e93-042

Foit FF, Gavin DG, Hu FS (2004) The tephra stratigraphy of two lakes in south-central British Columbia, Canada and its implications for midlate Holocene volcanic activity at Glacier Peak and Mount St. Helens, Washington, USA. Can J Earth Sci 41:1401-1410. https:// doi.org/10.1139/e04-081

Folk RL, Ward WC (1957) Brazos River bar [Texas]; a study in the significance of grain size parameters. J Sediment Res 27:3-26. https://doi.org/10.1306/74D 70646-2B21-11D 7$8648000102 \mathrm{C} 1865 \mathrm{D}$

Fontijn K, Rawson H, Van Daele M et al (2016) Synchronisation of sedimentary records using tephra: a postglacial tephrochronological model for the Chilean Lake District. Quat Sci Rev 137:234-254. https://doi.org/10.1016/j.quascirev.2016.02.015

Froggatt PC (1982) Review of methods of estimating rhyolitic tephra volumes; applications to the Taupo volcanic zone, New Zealand. J Volcanol Geotherm Res 14:301-318. https://doi.org/10.1016/03770273(82)90067-1

Gatti E, Oppenheimer C (2012) Utilization of distal tephra records for understanding climatic and environmental consequences of the Youngest Toba Tuff. Climates Landscapes Civilizations Geophys Monogr Ser 198:63-74. https://doi.org/10.1029/2012GM001216

Gatti E, Durant AJ, Gibbard PL, Oppenheimer C (2011) Youngest Toba Tuff in the Son Valley, India: a weak and discontinuous stratigraphic marker. Quat Sci Rev 30:3925-3934. https://doi.org/10.1016/j. quascirev.2011.10.008

Gatti E, Saidin M, Talib K et al (2013) Depositional processes of reworked tephra from the Late Pleistocene Youngest Toba Tuff deposits in the Lenggong Valley, Malaysia. Quat Res 79:228-241. https://doi.org/10.1016/j.yqres.2012.11.006 
Gertisser R, Self S (2015) The great 1815 eruption of Tambora and future risks from large-scale volcanism. Geol Today 31:132-136. https:// doi.org/10.1111/gto.12099

Geyer A, Martí J (2008) The new worldwide collapse caldera database (CCDB): a tool for studying and understanding caldera processes. J Volcanol Geotherm Res 175:334-354. https://doi.org/10.1016/j. jvolgeores.2008.03.017

Griggs AJ, Davies SM, Abbott PM, Coleman M, Palmer AP, Rasmussen TL, Johnston R (2015) Visualizing tephra deposits and sedimentary processes in the marine environment: the potential of X-ray microtomography. Geochem Geophys Geosyst 16:4329-4343. https://doi.org/10.1002/2015GC006073

Hadley D, Hufford GL, Simpson JJ (2004) Resuspension of relic volcanic ash and dust from Katmai: still an aviation hazard. Weather Forecast 19:829-840. https://doi.org/10.1175/1520-0434(2004)019<0829: RORVAA $>2.0 . \mathrm{CO} ; 2$

Hallett DJ, Hills LV, Clague JJ (1997) New accelerator mass spectrometry radiocarbon ages for the Mazama tephra layer from Kootenay National Park, British Columbia, Canada. Can J Earth Sci 34: 1202-1209. https://doi.org/10.1139/e17-096

Hammer CU, Clausen HB, Dansgaard W (1980) Greenland ice sheet evidence of post-glacial volcanism and its climatic impact. Nature 288:230-235. https://doi.org/10.1038/288230a0

Harward M, Youngberg C (1969) Soils from Mazama ash in Oregon identification, distribution and properties. In: Pedology and Quaternary Research Symposium. University of Alberta, Edmonton Alberta, pp 163-178

Heusser CJ (1974) Quaternary vegetation, climate, and glaciation of the Hoh River Valley, Washington. Geol Soc Am Bull 85:1547-1560. https://doi.org/10.1130/0016-7606(1974)85<1547:QVCAGO>2.0. $\mathrm{CO} ; 2$

Hopkins JL, Millet M-A, Timm C et al (2015) Tools and techniques for developing tephra stratigraphies in lake cores: a case study from the basaltic Auckland Volcanic Field, New Zealand. Quat Sci Rev 123: 58-75. https://doi.org/10.1016/j.quascirev.2015.06.014

Horwell CJ, Baxter PJ (2006) The respiratory health hazards of volcanic ash: a review for volcanic risk mitigation. Bull Volcanol 69:1-24. https://doi.org/10.1007/s00445-006-0052-y

Inoue $\mathrm{H}$ (1986) A least-squares smooth fitting for irregularly spaced data: finite-element approach using the cubic B-spline basis. Geophysics 51:2051-2066. https://doi.org/10.1190/1.1442060

Jensen BJL, Beaudoin AB, Clynne MA et al (2019) A re-examination of the three most prominent Holocene tephra deposits in western Canada: Bridge River, Mount St. Helens Yn and Mazama. Quat Int 500:83-95. https://doi.org/10.1016/j.quaint.2019.03.017

Johnston EN, Sparks RSJ, Phillips JC, Carey S (2014) Revised estimates for the volume of the Late Bronze Age Minoan eruption, Santorini, Greece. J Geol Soc 171:583-590. https://doi.org/10.1144/jgs2013113

Kandlbauer J, Sparks RSJ (2014) New estimates of the 1815 Tambora eruption volume. J Volcanol Geotherm Res 286:93-100. https://doi. org/10.1016/j.jvolgeores.2014.08.020

Kittleman LR (1973) Mineralogy, correlation, and grain-size distributions of Mazama tephra and other postglacial pyroclastic layers, Pacific Northwest. GSA Bull 84:2957-2980. https://doi.org/10.1130/00167606(1973)84<2957:MCAGDO>2.0.CO;2

Klawonn M, Houghton BF, Swanson DA et al (2014) From field data to volumes: constraining uncertainties in pyroclastic eruption parameters. Bull Volcanol 76:839. https://doi.org/10.1007/s00445-0140839-1

Lidstrom JW (1971) A new model for the formation of Crater Lake Caldera, Oregon. $\mathrm{PhD}$ Thesis, Oregon State University

Liu EJ, Cashman KV, Beckett FM et al (2014) Ash mists and brown snow: remobilization of volcanic ash from recent Icelandic eruptions. J Geophys Res Atmospheres 119:9463-9480. https://doi.org/ 10.1002/2014JD021598
Long CJ, Power MJ, Minckley TA, Hass AL (2014) The impact of Mt Mazama tephra deposition on forest vegetation in the Central Cascades, Oregon, USA. The Holocene 24:503-511. https://doi. org/10.1177/0959683613520258

Lowe DJ (2011) Tephrochronology and its application: a review. Quat Geochronol 6:107-153. https://doi.org/10.1016/j.quageo.2010.08. 003

Lowe DJ, Hogg AG, Green JD, Boubee JAT (1980) Stratigraphy and chronology of late Quaternary tephras in Lake Maratoto, Hamilton, New Zealand. N Z J Geol Geophys 23:481-485. https:// doi.org/10.1080/00288306.1980.10424118

MacGregor KR, Riihimaki CA, Myrbo A et al (2011) Geomorphic and climatic change over the past 12,900yr at Swiftcurrent Lake, Glacier National Park, Montana, USA. Quat Res 75:80-90. https://doi.org/ 10.1016/j.yqres.2010.08.005

Machida H (2002) Volcanoes and tephras in the Japan area. Global Environ Res Engl Ed 6:19-28

Manville V, Hodgson KA, Houghton BF et al (2000) Tephra, snow and water: complex sedimentary responses at an active snow-capped stratovolcano, Ruapehu, New Zealand. Bull Volcanol 62:278-293. https://doi.org/10.1007/s004450000096

Mason BG, Pyle DM, Oppenheimer C (2004) The size and frequency of the largest explosive eruptions on Earth. Bull Volcanol 66:735-748. https://doi.org/10.1007/s00445-004-0355-9

Matthews NE, Smith VC, Costa A et al (2012) Ultra-distal tephra deposits from super-eruptions: examples from Toba, Indonesia and Taupo Volcanic Zone, New Zealand. Quat Int 258:54-79. https://doi.org/ 10.1016/j.quaint.2011.07.010

Matz SE (1987) The effects of the Mazama tephra-falls: a geoarchaeological approach. Masters Thesis, Oregon State University

McFarland JR (1989) An analysis of two post-Mazama prehistoric flaked stone scatters in the upper Deschutes River basin of central Oregon. Masters Thesis, Oregon State University

McNamara K, Cashman KV, Rust AC et al (2018) Using lake sediment cores to improve Records of Volcanism at Aluto Volcano in the Main Ethiopian Rift. Geochem Geophys Geosyst 19:3164-3188. https://doi.org/10.1029/2018GC007686

McNamara K, Rust AC, Cashman KV, Castruccio A, Abarzúa AM (2019) Comparison of lake and land tephra records from the 2015 eruption of Calbuco volcano, Chile. Bull Volcanol 81:10. https://doi. org/10.1007/s00445-019-1270-4,15

Mehringer PJ, Arno SF, Petersen KL (1977) Postglacial history of lost trail pass bog, Bitterroot Mountains, Montana. Arct Alp Res 9:345368

Mullineaux D (1974) Pumice and other pyroclastic deposits erupted in Mount Rainier National Park, Washington. US Geol Surv Bull 1326:83p. https://doi.org/10.3133/b1326

Newhall C, Self S, Robock A (2018) Anticipating future Volcanic Explosivity Index (VEI) 7 eruptions and their chilling impacts. Geosphere 14:572-603. https://doi.org/10.1130/GES01513.1

Oetelaar GA, Beaudoin AB (2016) Evidence of cultural responses to the impact of the Mazama ash fall from deeply stratified archaeological sites in southern Alberta, Canada. Quat Int 394:17-36. https://doi. org/10.1016/j.quaint.2014.08.015

Panebianco JE, Mendez MJ, Buschiazzo DE, Bran D, Gaitán JJ (2017) Dynamics of volcanic ash remobilisation by wind through the Patagonian steppe after the eruption of Cordón Caulle, 2011. Sci Rep 7:45529. https://doi.org/10.1038/srep45529

Pye K (1995) The nature, origin and accumulation of loess. Quat Sci Rev 14:653-667. https://doi.org/10.1016/0277-3791(95)00047-X

Pyle DM (1989) The thickness, volume and grainsize of tephra fall deposits. Bull Volcanol 51:1-15

Pyle DM (2000) Sizes of volcanic eruptions. In: Sigurdsson H, Houghton $\mathrm{B}, \mathrm{McNutt} \mathrm{S}$ et al (eds) The encyclopedia of volcanoes. Academic Press, pp 257-264 
Pyne-O'Donnell SDF, Hughes PDM, Froese DG et al (2012) Highprecision ultra-distal Holocene tephrochronology in North America. Quat Sci Rev 52:6-11. https://doi.org/10.1016/j. quascirev.2012.07.024

Rougier J, Sparks RSJ, Cashman KV, Brown SK (2018) The global magnitude-frequency relationship for large explosive volcanic eruptions. Earth Planet Sci Lett 482:621-629. https://doi.org/10.1016/j. eps1.2017.11.015

Sarna-Wojcicki AM, Shipley S, Waitt RB Jr et al (1981) Areal distribution, thickness, mass, volume, and grain size of air-fall ash from the six major eruptions of 1980. US Geol Suv Prof Pap 1250:577-600

Self S (2006) The effects and consequences of very large explosive volcanic eruptions. Philos Trans R Soc A Math Phys Eng Sci 364. https://doi.org/10.1098/rsta.2006.1814

Shapley MD, Finney BP (2015) Lake morphometry controls the remobilization and long-term geochemical imprint of distal tephra deposition. J Paleolimnol 53:309-320. https://doi.org/10.1007/s10933015-9826-6

Spano NG, Lane CS, Francis SW, Johnson TC (2017) Discovery of Mount Mazama cryptotephra in Lake Superior (North America): implications and potential applications. Geology 45:1071-1074. https://doi.org/10.1130/G39394.1

Sun D, Bloemendal J, Rea DK et al (2004) Bimodal grain-size distribution of Chinese loess, and its palaeoclimatic implications. CATENA 55:325-340. https://doi.org/10.1016/S0341-8162(03)00109-7

Sweeney MR, Busacca AJ, Gaylord DR (2005) Topographic and climatic influences on accelerated loess accumulation since the last glacial maximum in the Palouse, Pacific northwest, USA. Quat Res 63: 261-273. https://doi.org/10.1016/j.yqres.2005.02.001

Thompson RS, Oviatt CG, Honke JS, McGeehin JP (2016) Chapter 11Late Quaternary changes in lakes, vegetation, and climate in the Bonneville Basin reconstructed from sediment cores from Great Salt Lake. In: Oviatt CG, Shroder JF (eds) Developments in earth surface processes. Elsevier, pp 221-291

Thorsteinsson T, Jóhannsson T, Stohl A, Kristiansen NI (2012) High levels of particulate matter in Iceland due to direct ash emissions by the Eyjafjallajökull eruption and resuspension of deposited ash. J Geophys Res Solid Earth:117. https://doi.org/10.1029/ 2011JB008756

Waitt RB (1980) About Forty Last-Glacial Lake Missoula Jökulhlaups through Southern Washington. J Geol 88:653-679. https://doi.org/ $10.1086 / 628553$

Watson EJ, Swindles GT, Lawson IT, Savov IP (2016) Do peatlands or lakes provide the most comprehensive distal tephra records? Quat Sci Rev 139:110-128. https://doi.org/10.1016/j.quascirev.2016.03. 011

Westgate JA, Dreimanis A (1967) Volcanic ash layers of recent age at Banff National Park, Alberta, Canada. Can J Earth Sci 4:155-161. https://doi.org/10.1139/e67-006

Westgate JA, Gorton MP (1981) Correlation techniques in tephra studies. In: Self S, Sparks RSJ (eds) Tephra studies. Springer Netherlands, Dordrecht, pp 73-94

Williams H (1942) The geology of Crater Lake National Park, Oregon: with a reconnaissance of the Cascade Range southward to Mount Shasta. Carnegie Inst Washington Publ 540:1-162

Williams H, Goles G (1968) Volume of the Mazama ash-fall and the origin of Crater Lake caldera. In: Andesite conference guidebook. Bull. Oreg. Dep. Geol. Mineral. Ind, pp 37-41

Wilson TM, Cole JW, Stewart C et al (2011) Ash storms: impacts of wind-remobilised volcanic ash on rural communities and agriculture following the 1991 Hudson eruption, southern Patagonia, Chile. Bull Volcanol 73:223-239. https://doi.org/10.1007/s00445-0100396-1

Young SR (1990) Physical volcanology of Holocene airfall deposits from Mt Mazama, Crater Lake, Oregon. PhD Thesis, University of Lancaster

Zdanowicz C, Zielinski G, Germani M (1999) Mount Mazama eruption: Calendrical age verified and atmospheric impact assessed. Geology 27:621-624. https://doi.org/10.1130/0091-7613(1999)027<0621: MMECAV>2.3.CO;2 